ANADOLU, J. of AARI

ISSN: $1300-0225$ (Print)

E-ISSN: 2667-6087 (Online)

2020, 30 (2): 179-196

DOI: $10.18615 /$ anadolu. 834905

\title{
Batı Akdeniz Bölgesi Yerel Yulaflarının bazı Tarımsal ve Kalite Özellikleri Yönünden Değerlendirilmesi
}

\author{
Murat ÇALIŞKAN ${ }^{1 *}$ (D) Ali KOÇ ${ }^{2}$ (D) Fatih Alpay VURAN ${ }^{3}$ (i) \\ Fulya YÜCEOL ${ }^{4}$ (D) Çetin SAYIL $\breve{G A N}{ }^{5}$ \\ ${ }^{1}$ Doğu Akdeniz Geçit Kuşağı Tarımsal Araştırma Enstitüsü,, Kahramanmaraş/TURKEY \\ ${ }^{2,3,4,5}$ Batı Akdeniz Tarımsal Araştırma Enstitüsü, Antalya TURKEY

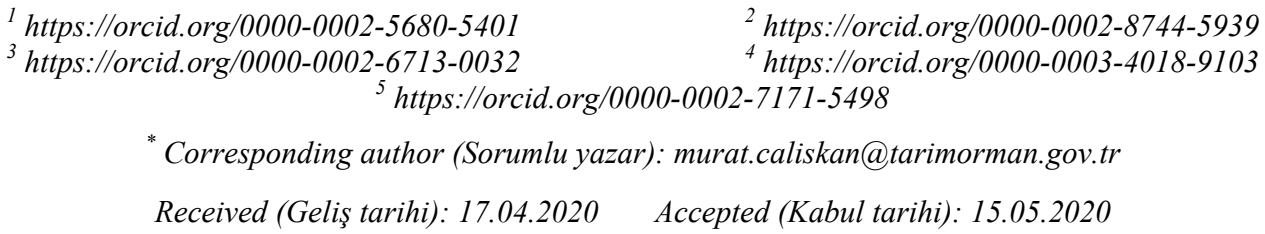

ÖZ: Bu çalışma Batı Akdeniz Bölgesi'nde yetiştirilen yerel yulaf çeşitlerinin bazı tarımsal ve kalite özelliklerinin belirlenmesi amaciyla yürütülmüştür. Antalya, Isparta, Burdur ve Muğla illerinden 164 adet yerel yulaf çeşidi toplanmış ve tanımlamaları yapılmıştır. Yerel çeşitlerden 74 adedinin Avena byzantina K. Koch, 90 adedinin Avena sativa L. türüne ait olduğu belirlenmiştir. Yerel çeşitler yedi ticari yulaf çeşidi ile birlikte 2015-2016 yetiştirme sezonunda Antalya koşullarında Augmented deneme planinda tarlaya ekilmiştir. Yerel çeşitlerin salkım gösterme süresi (SGS), fizyolojik olum süresi (FOS), salkımda başakçık sayısı (SBS), salkımda tane sayısı (STS), salkımda tane ağırlı̆̆ (STA), yatma (Y), biyolojik verim (BV), tane verimi (TV), kavuzsuz tane oranı (KTO), bin tane ă̆ırlığı (BTA), tane protein oranı (TPO) ve tane yağ oranı (YO) özellikleri incelenmiştir. Populasyonlar arası varyasyonları belirlemek için ortalamaları, standart sapmaları ve değişim katsayıları hesaplanmıştır. Bazı özellikler bakımından yerel çeşitler arasında yüksek varyasyon olduğu tespit edilmiştir. Yerel çeşitler arasında SGS, FOS, SBS, STS, STA, TV ve BTA bakımından önemli farklar bulunurken; BV, KTO, TPO ve YO bakımından farklar önemli bulunmamıştır. Yerel çeşitlerin TPO'ları \%7,56 ile \%21,25 arasında, YO'ları ise \%2,71 ile \%8,57 arasında değişmiştir. Yerel çeşitlerin tane verimleri Faikbey ve Seydişehir çeşitleri hariç standart çeşitlerden daha düşük bulunmuş, bunun yatmaya ve hastalıklara karşı hassas olmalarından kaynaklanabileceği sonucuna varılmıştır.

Anahtar Kelimeler: Yulaf, Avena sativa L., yerel çeşit, tarımsal özellikler, kalite, Batı Akdeniz Bölgesi.

\section{Evaluation of Oat Landraces of the Western Mediterranean Region in Terms of some Agricultural and Quality Traits}

ABSTRACT: This study was carried out to determine some agronomic and quality characteristics of oat landraces are grown in the Western Mediterranean Region. 164 oat landraces from Antalya, Isparta, Burdur and Muğla provinces were collected and identified. It was determined that 74 landraces belong to Avena byzantina K. Koch, and 90 landraces belong to Avena sativa L.. The oat landraces and seven commercial oat varieties were sown via Augmented experiment design in Antalya in 2015-2016 growing season. The traits of landraces such as days to panicle emergence (DPE), days to maturity (DM), spikelet number per panicle (SNP), grain number per panicle (GNP), grain weight per panicle (GWP), lodging (L), biomass yield (BY), grain yield $(G Y)$, groat percentage (GP), thousand kernel weight (TKW), grain protein ratio (GPR) and grain oil ratio (GOR) were investigated. Averages, standard deviations, and coefficients of variation were calculated to determine variations among landraces. In terms of some features, high variation has been found among oat landraces. Although significant differences were found among the genotypes in terms of DPE, DM, SNP, GNP, GWP, GY and TKW features, they weren't found in terms of GNS, $G D, B Y, G P, G P R$, and GOR features. The GPR of landraces ranged between $7.56 \%$ and $21.25 \%$, and GOR ranged between $2.71 \%$ and $8.57 \%$. Grain yields of landraces were determined lower than the standard varieties except for Faikbey and Seydişehir varieties, and it was concluded that this may be due to their susceptibility to lodging and diseases.

Keywords: Oat, Avena sativa L., landrace, agronomic traits, quality, Western Mediterranean Region. 


\section{GíRIŞ̧}

Yulaf (Avena sativa L.) buğdaygiller (Poaceae) familyasının bir üyesidir ve ülkemizde yaklaşık olarak 11 takson ile temsil edilmektedir. Dünyada Avena sativa L., Avena byzantina K. Koch ve Avena nuda L. türlerinin kültürü yapılmaktadır (Davis ve ark., 1985; Güner ve ark., 2012). Yulaf buğday ve arpadan sonra kültüre alınmıştır. Yulaf diğer tahıllara göre verimli toprak tiplerine daha iyi uyum sağlar ve asitli topraklarda daha iyi yetişebilir. Salkım gösterme ile olgunlaşma arası dönemde sıcak ve kuru havaya karşı hassas olabilirler. Yulaf çimlenmeden salkım göstermeye kadar sıcaklığ $15^{\circ} \mathrm{C}$ 'yi aşmayan serin bir hava ve yüksek nem ister. Yağışı 700-800 mm olan yöreler yulaf tarımı için uygundur. Ancak bu bölgelerde yulafta yatma problemi görülebilmektedir. Kurağa dayanıklı olmayan yulaf, kıșa da dayanıklı değildir (Kün,1988). Bu nedenle kışlık tahıl ekimi yapılan bölgelerde, yulaf erken ilkbaharda ekilmektedir. $\mathrm{Bu}$ bölgelerdeki kıraç alanlarda yapılan yazlık ekimlerde yulafin nem ihtiyacinın fazla olması nedeniyle verim düşük olmaktadır (Dokuyucu ve ark., 2010). 2018 y1lı istatistiklerine göre dünyada yulaf ekim alanı 9,8 milyon hektardır ve bu alandan ortalama $234 \mathrm{~kg} / \mathrm{da}$ verim ile 23 milyon tonluk bir üretim gerçekleştirilmiştir. Dünyada 78 ülkede yulaf üretimi yapılmakta, \%21'lik payla Rusya Federasyonu ilk sirada yer almakta, onu $\% 15$ ile Kanada ve \%5 ile Avusturalya takip etmektedir. Ülkemizde serin iklim tahılları arasında üretim miktarı bakımından buğday, arpa ve çavdardan sonra gelen yulafin 2018 yılında 106 bin hektar alanda ekimi yapılmış, $246 \mathrm{~kg} / \mathrm{da}$ verimle 260 bin ton üretim gerçekleşmiş, üretim bakımından dünyada \%1,1'lik paya sahip olmuştur (Anonymous, 2020).

Eskiden beri tanesi ve otu için yetiștirilen bir tahıl olan yulaf, besin değerinin anlaşılmasıyla, son y1llarda insan beslenmesinde de yoğun bir şekilde kullanılmaya başlanmıştır. Hem insan gıdası hem de hayvan yemi olarak kullanılmasının yanında kozmetik ve ilaç sanayisinde artan önemi (Batalova ve ark., 2016; Sabandüzen ve Akçura, 2017; Akay ve ark., 2019) ile yulaf tanesi ve bitkisine olan talep gün geçtikçe artmaktadır. Yulafta bulunan ve beta glukan ismi verilen çözünebilir lif bileşeninin insanlarda bağışıklık sistemini güçlendirdiği ve kandaki kolesterol seviyesini düşürdüğü bildirilmiştir
(Tsikitis ve ark., 2004; Tiwari ve Cummins, 2009). İnsan beslenmesinde kullanilan yulaf tanesinin protein ve çözülebilir lif (beta glukan) oranının yüksek, yağ oranın ise düşük olması tercih edilmektedir (Peterson ve ark., 2005).

Akdeniz ve Yakın Doğu ana gen merkezlerinin kesişme noktasında yer alan Türkiye, bitki genetik çeșitliliği bakımından oldukça zengindir (Anonim, 2007). Sürdürülebilir bir tarım için ülkemizdeki gen kaynaklarının toplanması, korunması ve tanımlamalarının yapılmasi gelecekteki islah çalışmaları için çok önemlidir. Malzew (1930), yulafın kökeninin Anadolu olduğunu bildirmiştir. Kültürü yapılan beyaz yulaf (Avena sativa L.) ve kırmızı yulaf (Avena byzantina K. Koch) ülkemizin bitkisel genetik kaynaklarındandır. Bu çalışma ile Antalya, Muğla, Isparta ve Burdur illerinde kültürü yapılan yerel yulaf çeşitleri, diğer bir ifade ile köy çeşitleri (köy populasyonları) toplanmıștır. Yerel yulafların tohum örnekleri toplama bilgileri ile birlikte Ankara'da bulunan Türkiye Tohum Gen Bankasına teslim edilerek koruma altına alınmıştır. Ayrıca, toplanan yerel yulaflar, tescil edilmiş yulaf çeşitleriyle Antalya koşullarında tarla denemesine alınmış ve bazı tarımsal ve kalite özellikleri incelenmiştir.

\section{MATERYAL ve METOT}

Araştırmanın bitkisel materyalini Antalya, Muğla, Isparta ve Burdur'dan toplanan 164 adet yerel yulaf çeșidi oluşturmuștur. Yerel çeșitlerin tür teşhislerinde "Flora of Turkey and the East Aegean Islands" eserinden (Davis ve ark., 1985) ve diğer ülke floralarından (Rechinger, 1970; Tutin ve ark., 1980) yararlanılmıştır. Teşhis için bitkilerin kılçık şekli, kılçık sayısı, ilk büyüme şekli, salkım uzunluğu, başakçık ekseninin (rachilla) kırılma şekli özelliklerine bakılmıştır. Toplanan yerel çeşitler toplandığ 1 illere ve botanik türüne göre Çizelge 1'de verilmiştir.

Toplanan yerel yulaf çeşitleri kontrol olarak kullanılan Seydișehir, Faikbey, Yeniçeri, Sarı, Fetih, Kahraman ve Kırklar çeșitleri ile birlikte tarla denemesine alınmıştır. Deneme Batı Akdeniz Tarımsal Araştırma Enstitüsünün Aksu Birimindeki deneme tarlasina 5 Kasim 2015 tarihinde ekilmiştir. Ekimle birlikte dekara $6 \mathrm{~kg} \mathrm{~N} \mathrm{P} \mathrm{K}$ olacak şekilde 15-15-15 kompoze gübre verilmiştir. 
Deneme Augmented deneme planına göre 4 blok halinde ve metrekareye 450 tohum olacak şekilde 6 $\mathrm{m}^{2}$ ’lik $(1,2 \mathrm{~m} \times 5 \mathrm{~m})$ parsellere ekilmiştir. Kontrol çeşitleri 4 tekerrürlü, Yerel çeşitler ise denemede bir kez yer almıştır. Yabancı ot mücadelesi kimyasal yolla yapılmıştır. Denemenin yürütüldüğü yetiştirme sezonundaki aylık sicaklık değerleri uzun yıllar ortalamasindan yüksek seyrederken, yetiştirme sezonunda alınan yağış miktarı ise uzun yılların ortalamasından düşük olmuştur (Şekil 1).

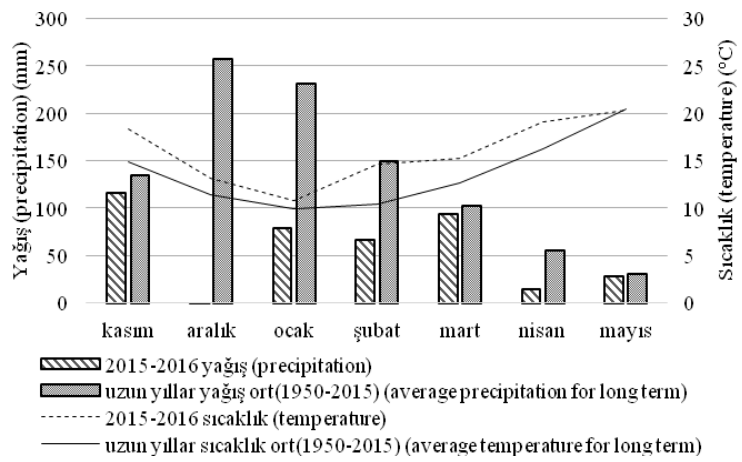

Şekil 1. 2015-2016 ürün yetiştirme sezonuna ve uzun yıllara ait aylık ortalama sıcaklık ve yağış değerleri (Anonim, 2016). Figure 1 . Monthly average temperature and precipitation values for the 2015-2016 crop season and long term (Anonim, 2016).

Tarla denemesindeki gözlem ve ölçümler için Dokuyucu ve ark. (2010) ile Mut ve ark. (2011)'nın kullandığ 1 yöntemler esas alınmıştır. Gözlemler ve ölçümler parsellerin orta yerinde işaretlenen 1 metrelik kısımdan 10'ar bitki üzerinden alınmıştır. Denemede yerel çeşitlerin salkım gösterme süresi, fizyolojik olum süresi, salkımda başakçık sayısı, salkımda tane sayısı, salkımda tane ağırlığı, yatma, biyolojik verim, tane verimi, kavuzsuz tane oranı, bin tane ağırlı $\breve{1}$, tane protein oranı ve tane yağ oranı özellikleri incelenmiştir. Tanedeki protein oranı Kjeldahl yöntemiyle (AOAC, "Official methods of analysis", method 979.09) tayin edilmiștir (Anonymous, 1990). Tanedeki yă oranı ise Soxhlet ekstraksiyon yöntemiyle (AOAC, method 945.16) belirlenmiştir (Anonymous, 2005). Yerel çeşitlerin yatma durumlarının tespitinde 1-9 skalası kullanılmıştır. Buna göre 1: yatma yok, 3: düşük, 5: orta, 7: yüksek ve 9: çok yüksek, olarak değerlendirilmiştir (Buerstmayr ve ark., 2007). Bu skala değerleri gözleme dayalı olduğundan varyans analizine tabi tutulmamıştır. Elde edilen diğer veriler Augmented deneme deseni planına uygun olarak varyans analizine tabi tutulmuştur. Populasyonlar arası çeşitliliği belirlemek için düzeltilmiș ortalamalar kullanılarak basit istatistiksel (ortalama, minimum, maksimum, standart sapma, değişim katsayısı) değerlendirmeler yapılmıştır (Yurtsever, 1984). Varyans analizleri, korelasyon analizi ve ortalamaların dağılım grafikleri JMP paket programında yapılmıştır (Anonymous, 2007). Yerel çeşitlerin karşılaştırılması Asgari Önemli Fark (LSD) metoduna göre yapılmıştır. Asgari Önemli Fark değerleri aşağıdaki eşitliklere göre hesaplanmıştır (Petersen, 1994). Denemede kontrol olarak yer alan standart çeşitlerin birbirleriyle karşılaştırılmasında;

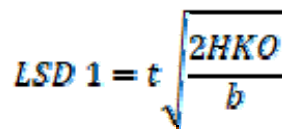

Çizelge 1. Batı Akdeniz Bölgesi'nden toplanan yerel yulaf çeşitleri.

Table 1. Oat landraces collected from the Western Mediterranean Region.

\begin{tabular}{|c|c|c|}
\hline \multirow{2}{*}{$\begin{array}{l}\text { İl } \\
\text { Province }\end{array}$} & \multicolumn{2}{|c|}{ Yerel çeşit no (Landrace no.) } \\
\hline & A. sativa $\mathrm{L}$. & A. byzantina K. Koch \\
\hline Antalya & $\begin{array}{l}46,74,75,76,77,78,79,80,81,82,83,84,85, \\
104,105,143,144,145,146,147,152,159,160, \\
164\end{array}$ & $\begin{array}{l}1,2,3,4,5,6,7,8,9,10,11,12,13,14,15,16,17, \\
18,19,20,21,22,23,24,25,26,27,28,29,30,31 \text {, } \\
32,33,34,35,36,37,42,43,44,45,47,48,49\end{array}$ \\
\hline Muğla & $39,52,149,150,151$ & $\begin{array}{l}38,40,41,50,51,53,54,55,56,57,58,59,60,61, \\
62,63,64,65,66,67,68,69,70,71,72,73,148\end{array}$ \\
\hline Isparta & $\begin{array}{l}106,107,108,109,111,112,114,115,116,117, \\
118,119,120,121,122,123,124,125,126,127, \\
128,129,130,131\end{array}$ & 110,113 \\
\hline Burdur & $\begin{array}{l}87,88,89,90,91,92,93,94,95,96,97,98,99, \\
100,101,102,103,132,133,134,135,136,137, \\
138,139,140,141,142,153,154,155,156,157, \\
158,161,162,163\end{array}$ & 86 \\
\hline
\end{tabular}


Kontrol çeşitlerin değerleri ile yerel çeşitlerin düzeltilmiş değerlerinin karşılaştırılmasında;

$$
L S D 2=t \sqrt{\frac{(b+1)(k+1) H K O}{b k}}
$$

eşitlikleri kullanılmıştır. Eşitlikte LSD Asgari Önemli Fark1, HKO kontrol çeşitlerin incelenen özelliklerine ait varyans analizi tablosundaki Hatanın Kareler Ortalamasını, $k$ kontrol çeşit sayısın1, $b$ blok sayısını, $t$ hata serbestlik dereceli 0,05 düzeyindeki iki yönlü tablo $t$ değerini ifade etmektedir (Ergün ve Geçit, 2008).

\section{BULGULAR ve TARTIŞMA}

\section{Salkım gösterme süresi}

Salkım gösterme süresi (SGS) bakımından yerel çeşitler arasındaki farklar istatistiki olarak önemli bulunmuştur $(\mathrm{P}<0,01)$. Yerel çeşitlerin salkım gösterme süreleri 143,10 gün ile 171,10 gün arasında değişirken; ortalaması, populasyonlar arası standart sapma ve değişim katsayısı sırasıyla 157,20 gün, 4,10 gün ve $\% 2,61$ olarak belirlenmiştir (Çizelge 2). Yerel çeşitlerden 64 (Muğla; AB- A. byzantina K. Koch) ve 66 (Muğla; AB) numaralı olanlar en kısa salkım gösterme süresine sahip olurken, 80 (Antalya; AS- A. sativa L.), 84 (Antalya; AS) ve 104 (Antalya; AS) numaralı yerel çeşitler en uzun salkım gösterme süresine sahip olmuştur. Bununla birlikte yerel çeşitlerin çoğunluğu (\%92,7'si) 150,00 gün ile 162,50 gün arasında salkım göstermiştir (Şekil 2). Standart çeşitlerin salkım gösterme süreleri 135,50 ile 166,30 gün arasında değişmiş ve standartların ortalaması 154,90 gün olmuştur. En erken salkım gösteren çeşit Sarı, en geç salkım gösteren çeşit Seydişehir olmuştur. Daha önce yapılan bazı çalışmalarda da benzer sonuçlar elde edilmiştir. Bazı araştırmacılar yaptıkları çalışmalarda salkım gösterme süreleri bakımından genotipler arasında önemli farklar olduğunu belirterek bu farklılığın çeşitlerin genetik özelliklerinden kaynaklandığını bildirmişlerdir (Nawaz ve ark., 2004; Dokuyucu ve ark., 2010; Mut ve ark., 2011; Erbaş, 2012; Dumlupınar ve ark., 2015; Dumlupinar ve ark., 2017; Naneli ve Sakin, 2017).

\section{Fizyolojik olum süresi}

Fizyolojik olum süresi (FOS) bakımından yerel çeşitler arasındaki farklar istatistiki olarak önemli bulunmuştur $(\mathrm{P}<0,01)$. Yerel çeşitlerin olgunlaşma süreleri 183,80 gün ile 199,10 gün arasında değişirken; ortalamalar1, populasyonlar aras1 standart sapmas1 ve değişim katsayısı sırasıyla 190,90 gün, 3,54 gün ve \%1,85 olmuştur (Çizelge 2). Yerel çeşitlerin olgunlaşma sürelerine göre dağılımı Şekil 2'de gösterilmiştir. Yerel çeşitlerden 106 (Isparta; AS), 62 (Muğla; $\mathrm{AB}$ ) ve 66 (Muğla; $\mathrm{AB}$ ) numaralı olanlar en erken olgunlaşırken; 80 (Antalya; AS), 84 (Antalya; AS), 104 (Antalya; AS) numaralı olanlar en geç olgunlaşan yerel çeşitler olmuştur. Standart çeşitlerin olgunlaşma süreleri 182,30 ile 193,30 gün arasında değişmiş, standartların ortalaması 188,10 gün olmuştur. En erken olgunlaşan çeşit Sarı, en geç olgunlaşan çeşit Seydişehir olmuştur. Ercan ve ark. (2016), Kahramanmaraş koşullarında yürüttükleri araştırmada fizyolojik olum süresi yönünden genotipler arasındaki farkların önemli olduğunu $(\mathrm{P}<0,01)$ belirtmişlerdir. Aynı araştırmacılar standart çeşitlerde fizyolojik olum sürelerinin 173,00 ile 185,00 gün arasında, yerel çeşitlerde ise bu sürenin 178,00 ile 194,00 gün arasında değiştiğini bildirmişlerdir. Daha önce yapılan bazı çalışmalarda da benzer sonuçlar elde edilmiştir. Bazı araştırmacılar yaptıkları çalışmalarda olgunlaşma süresi bakımından genotipler arasındaki farkların istatistiki bakımdan önemli olduğunu belirtmişlerdir (Nawaz ve ark., 2004; Dokuyucu ve ark., 2010; Mut ve ark., 2011; Dumlupinar ve ark., 2015; Narlıoglu, 2015). Nawaz ve ark. (2004), araştırmalarında bu farklılıkların genotiplerden kaynaklandığını bildirmiş̧lerdir.

\section{Salkımda başakçık sayısı}

Salkımda başakçık sayısı (SBS) bakımından yerel çeşitler arasında farklar önemli bulunmuştur $(\mathrm{P}<0,05)$. Yerel çeşitlere ait populasyonlar arası standart sapma 9,74 adet, değişim katsayısı $\% 19,10$ ve ortalamaları 51,00 adet olarak belirlenmiştir (Çizelge 2). Salkımda en düşük başakçık sayısı 120 (Isparta; AS) numaralı yerel çeşitten 21,60 adet ile elde edilmiş, bunu 26,50 adet ile 116 (Isparta; AS) numaralı yerel çeşit izlemiştir. En yüksek salkımda başakçık sayısı 75,80 adet ile 164 (Antalya; AS) numaralı yerel çeşitten alınmış, bunu 74,80 adet ile 
135 (Burdur; AS) numaralı yerel çeşit izlemiştir. Yerel çeşitlerin salkımda başakçık sayılarına göre dağılımları Şekil 2'de verilmiştir. Yerel çeşitlerde 30,00 adetten düşük salkımda başakçık sayısına sahip 2 yerel çeşit, 70,00 adetten yüksek ise 3 adet yerel çeşit bulunmuş, bununla birlikte 40,00 ile 60,00 adet arasında bir yığılma olmuştur. Standart çeşitlerin salkımda başakçı sayıları 44,50 adet ile 66,90 adet arasında değişmiş, ortalamaları ise 57,00 adet olmuştur. Yeniçeri standartlar içerisinde en yüksek salkımda başakçık sayısına sahip olurken, bunu 66,10 adet ile Kırklar çeşidi takip etmiştir. En düşük salkımda başakçık sayısı Faikbey çeşidinden alınmıştır. Standart çeşitlerin ortalaması yerel çeşitlerin ortalamasından daha yüksek bulunmuştur. Erbaş (2012), yaptığı araştırmada yulaf genotipleri arasında salkımda başakçık sayısı bakımından önemli farklar bulunduğunu ve 9,40 ile 49,80 adet arasında değiştiğini tespit etmiştir. Sar1 (2012), bu konuda yaptığ iki yıl süren araştırmada salkımda başakçık sayısı bakımından genotipler arasında önemli farklar olduğunu, ilk yıl değerlerinin 26,40 ile 92,50 adet arasında, ikinci yılda ise 26,85 ile 82,60 adet arasında değiştiğini tespit etmiştir. Mut ve ark. (2011), yaptıkları araştırmada salkımda başakçık sayısının ilk yıl 23,88 ile 94,32 adet arasında, ikinci yetiştirme y1lında ise 18,69 ile 81,38 adet arasında değiştiğini ve yerel çeşitler arasında büyük bir varyasyonun olduğunu belirtmişlerdir.

\section{Salkımda tane sayısı}

Yerel çeşitler arasında salkımda tane sayısı (STS) bakımından önemli farklar bulunmuştur $(\mathrm{P}<0,05)$. Yerel çeşitlere ait populasyonlar arası standart sapma 18,43 adet, değişim katsayısı $\% 24,70$ ve ortalamaları 74,70 adet olarak belirlenmiștir (Çizelge 2). 110 (Isparta; AB) numaralı yerel çeşit 33,00 adet ile en düşük salkımda tane sayısı değerine sahip olurken, bunu 35,60 adet ile 115 (Isparta; AS) numaralı yerel çeşit izlemiştir. En yüksek salkımda tane sayısı 122,20 adet ile 66 (Muğla; AB) numaralı yerel çeşitten alınmış, bunu 115,80 adet ile 40 (Muğla; AB) numaralı yerel çeşit izlemiştir. Yerel çeşitlerin salkımda tane sayılarına göre dağılımları Şekil 2'de verilmiştir. Yerel çeşitlerde 50,00 adetten düşük salkımda tane sayısina sahip 14, 50,00 ile 90,00 adet arasi 119, 90,00 adetten fazla olan 31 yerel çeşit bulunmuştur.
Standart cessitlerin salkımda tane sayıları 44,90 adet ile 113,70 adet arasında değişmiş, ortalamaları ise 85,20 adet olmuştur. Yeniçeri çeşidi standartlar içerisinde en yüksek salkımda tane sayısına sahip olurken, bunu 99,00 adet ile Sarı çeşidi takip etmiştir. En düşük salkımda tane sayısı Faikbey çeşidinden alınmıştır. Standart çeşitlerin ortalaması yerel çeşitlerin ortalamasından daha yüksek bulunmuştur. Ercan ve ark. (2016), yaptıkları araştırmada salkımdaki tane sayısı yönünden genotipler arasındaki farkları önemli bulmuşlardır $(\mathrm{P}<0,01)$. Aynı araştırmacılar standart çeşitlerde salkımda tane sayısının 47,00 ile 93,00 arasında, yerel çeşitlerde ise 47,00 ile 215,00 tane arasında değiştiğini belirtmişlerdir. Hışır (2009), iki yıl süreyle yürüttüğü araştırmada ilk yıl genotipler arasındaki farkların önemsiz, ikinci yıl önemli olduğunu bildirmiştir. Yapılan diğer bazı araștırmalarda da salkımda tane sayısı bakımından genotipler arasında önemli farklar tespit edilmiştir (Geçit ve Şahin, 1999; Gül ve ark., 1999; Kara ve ark., 2007; Maral, 2009; Dokuyucu ve ark., 2010; Mut ve ark., 2011; Erbaş, 2012; Sarı, 2012; Ceyhan, 2015; Narlığlu, 2015). Dumlupınar ve ark. (2015) ise her iki yılda da genotipler arasındaki farkların önemsiz olduğunu belirtmişlerdir.

\section{Salkımda tane ağırlığı}

Salkımda tane ağırlı̆̆ı (STA) bakımından yerel çeşitler arasında önemli farklar bulunmuştur $(\mathrm{P}<0,01)$. Yerel çeşitlere ait populasyonlar arası standart sapma $0,85 \mathrm{~g}$, değişim katsayısı $\% 42,00$ ve ortalamaları 2,03 g olarak belirlenmiştir (Çizelge 2). 109 (Isparta; AS) numaralı yerel çeşit $0,44 \mathrm{~g}$ ile en düşük salkımda tane ağırlığ değerine sahip olurken, bunu $0,47 \mathrm{~g}$ ile 105 (Antalya; AS) numaralı yerel çeşit izlemiştir. En yüksek salkımda tane ağırlığ1 5,62 g ile 66 (Muğla; AB) numaralı yerel çeşitten alınmış, bunu 3,88 g ile 40 (Muğla; AB) numaralı yerel çeşit izlemiştir. Yerel çeşitlerin salkımda tane ağırlığına göre dağılımları Şekil 2'de verilmiștir. Yerel çeșitlerde 1,00 g altında salkımda tane ağırlığına sahip 13 yerel çeşit, $1,00 \mathrm{~g}$ ile 3,50 $\mathrm{g}$ aras1 146 yerel çeşit, 3,50 g üzeri olan 5 yerel çeşit bulunmuştur. Standart çeşitlerin salkımda tane ağırlığ $1,20 \mathrm{~g}$ ile 4,45 g arasında değişmiş, ortalamaları ise 3,03 g olmuştur. Sarı çeşidi standartlar içerisinde en yüksek salkımda tane ağırlığına sahip olurken, bunu 4,33 g ile Kırklar 
çeşidi takip etmiştir. En düşük salkımda tane ağırlığı Faikbey çeşidinden elde edilmiştir. Standart çeşitlerin ortalamasının yerel çeşitlerin ortalamasından daha yüksek olduğu belirlenmiştir. Ercan ve ark. (2016), yaptıkları araştırmada salkım tane ağırlı̆̆ yönünden genotipler arasında önemli farklar tespit etmişlerdir. Araştırmacılar standart çeşitlerde salkımdaki tane ağırlığ 1,46 ile $3,20 \mathrm{~g}$ arasında, yerel çeşitlerde ise 4,77 g ile 1,23 g arasında değiştiğini saptamışlardır. $\mathrm{Bu}$ sonuçlar bizim bulgularımızı desteklemektedir. Yapılan bazı araştırmalarda da salkımdaki tane ağırlığının çeşitlere göre değiştiği bildirilmiştir (Geçit ve Şahin, 1999; Gül ve ark., 1999; Kara ve ark., 2007; Maral, 2009; Dokuyucu ve ark., 2010; Sarı, 2012; Narlığlu, 2015; Naneli ve Sakin, 2017).

\section{Yatma}

Yatma (Y) skala değerlerine göre en düşük skala değerlerine 80 (Antalya; AS) ve 84 (Antalya; AS) numaralı yerel çeşitler (skala değeri 3) sahip olmuştur. Bunları 5 skala değeri ile 83 (Antalya; AS), 104 (Antalya; AS) ve 164 (Antalya; AS) numaralı yerel çeşitler izlemiştir. Bundan başka 24 adet yerel çeşidin skala değeri 7, 135 adet yerel çeşidin skala değeri 9 olarak tespit edilmiştir (Şekil 2). Standartlar içerisinde Fetih çeşidi yatma göstermemiş (skala değeri 1) ve yatmaya en dayanıklı çeşit olmuştur. Bu çeşidi 3 skala değeri ile Sarı ve 5 skala değeri ile Yeniçeri izlemiştir. Faikbey ve Seydişehir çeşitlerinde çok yüksek bir yatma (skala değeri 9) görülmüştür. Ülkemizde yulaf bitkisinin en önemli sorunlarından bir tanesi yatmasıdır. Yatma problemi bitki boyu yüksek olan yulaf bitkisi için sıç̧a görülebilen bir durumdur. Ülkemizde tarımı yapılan yerel yulafların genellikle yüksek boylu olması yatmaya neden olmaktadır. Sap kalınlığı ve bitki boyu yatma problemi bulunan yulaf bitkisi için önemli özelliklerdir. Bununla ilgili daha önce yapılan araştırmalarda, iklim koşullarının yatmaya etkili olduğu (Tamm, 2003), genotiplere göre değiştiği ve önemli genetik kalıtım gösterdiği bildirilmiştir (Buerstmayr ve ark., 2007; Dokuyucu ve ark., 2010; Dumlupınar, 2010; Naneli ve Sakin, 2017). Bununla birlikte, Sainio ve Jarvinen (1995), optimum ekim oranında, yatmaya hassas uzun saplı genotiplerin çevresel koşullara orta ve kisa boylu genotiplere göre daha fazla bağımlı olduğunu belirtmişlerdir. Yaptığımız araştırmada yerel çeşitlerin yatma özelliklerinin, genetik yapılarından kaynaklandığı, bununla birlikte, iklim şartları ile gübreleme ve bir önceki ürün olan susamdan toprakta arta kalan azotun da yatmay teşvik ettiği düşünülmektedir (Şener ve ark., 2017). Kün (1988), ön bitkiye verilmiş gübrenin toprakta kalanından yulafın çok iyi yararlandığını bildirmiştir.

\section{Biyolojik verim}

Biyolojik verim (BV) bakımından yerel çeşitler arasındaki farklar önemsiz bulunmuştur. Yerel çeşitlere ait populasyonlar arası standart sapma $640,27 \mathrm{~kg} / \mathrm{da}$, değişim katsayısı \%27,20 ve ortalamalar1 $2.354,00 \mathrm{~kg} / \mathrm{da}$ olarak belirlenmiştir (Çizelge 2). Yerel yulaf çeşitlerinin biyolojik verimleri $1.059,00 \mathrm{~kg} / \mathrm{da}$ ile $4.418,00 \mathrm{~kg} / \mathrm{da}$ arasında değişmiştir. Yerel çeşitlerden 87 (Burdur; AS) numaralı olan en düşük biyolojik verim değerine sahip olmuş, bunu $1.096,00 \mathrm{~kg} / \mathrm{da}$ verimle 61 (Muğla; AB) numaralı yerel çeşit izlemiştir. En yüksek biyolojik verim değerleri 33 (Antalya; $A B$ ), 9 (Antalya; AB), 35 (Antalya; AB) ve 20 (Antalya; $\mathrm{AB}$ ) numaralı yerel çeşitlerden (sırasıyla 4.418,00; $4.268,00 ; 4.184,00$ ve $4.101,00 \mathrm{~kg} / \mathrm{da}$ ) elde edilmiştir. Yerel çeşitlerin biyolojik verimlerine göre dağılımları Şekil 2'de verilmiştir. Yerel çeşitlerin büyük çoğunluğu (yaklaşık \%61,6's1) biyolojik verim bakımından $1.750,00 \mathrm{~kg} / \mathrm{da}$ ile $2.750,00 \mathrm{~kg} / \mathrm{da}$ arasında değer almıştır. Standart çeşitlerin biyolojik verimleri $2.421,00 \mathrm{~kg} / \mathrm{da}$ ile $4.508,00 \mathrm{~kg} / \mathrm{da}$ arasında değişmiş, ortalamaları ise $3.320,00 \mathrm{~kg} / \mathrm{da}$ olmuştur. Yeniçeri çeşidi standartlar içerisinde en yüksek biyolojik verime sahip olurken, bunu $3.700,00 \mathrm{~kg} / \mathrm{da}$ ile Kırklar çeşidi izlemiştir. En düşük biyolojik verim ise Faikbey çeşidinden elde edilmiştir. Standart çeşitlerin ortalamaları yerel çeşitlerin ortalamasından daha yüksek olmuştur. Bununla birlikte standart çeşitlerin ortalamasından daha yüksek değere sahip yerel çeşitlerin de olduğu saptanmıştır. Dreccer ve ark. (2009), konu ile ilgili yaptığı araştırmada çeşitler arasında önemli bir farklılık bulamazken, diğer bazı araştırmalarda ise bu çalışmanın aksine biyolojik verim yönünden çeşitler arasındaki farkların önemli olduğu belirlenmiştir (Hışır, 2009; Maral, 2009; Erbaş, 2012). Dokuyucu ve ark. (2010), tek bitki biyolojik verimi bakımından araştırmanın ilk yilında genotipler arasında geniş bir varyasyon görüldüğünü, ikinci yılda ise verim ve verim 
unsurları bakımından yapılan seleksiyona göre elde edilen genotiplerin kullanılması nedeniyle genotipler arasındaki farkların önemli çıkmadığını bildirmiştir. Mut ve ark. (2011), yaptıkları araştırmada biyolojik verimin ilk y1l $612,50 \mathrm{~kg} / \mathrm{da}$ ile $2.800,00 \mathrm{~kg} / \mathrm{da}$ arasında, ikinci yetiştirme y1lında ise $648,10 \mathrm{~kg} / \mathrm{da}$ ile $2.194,00 \mathrm{~kg} / \mathrm{da}$ arasında değiştiğini saptamışlardır.

\section{Tane verimi}

Tane verimi (TV) bakımından yerel çeşitler arasında önemli farklar bulunmuştur $(\mathrm{P}<0,01)$. Yerel çeşitlere ait populasyonlar arası standart sapma 33,30 kg/da, değişim katsayıs1 \%43,04 ve ortalamaları $77,40 \mathrm{~kg} / \mathrm{da}$ olarak belirlenmiştir (Çizelge 2). Yerel yulaf çeşitlerinin tane verimleri $168,00 \mathrm{~kg} / \mathrm{da}$ ile $25,00 \mathrm{~kg} / \mathrm{da}$ arasında değişmiştir. Yerel çeşitlerden 125 (Isparta; AS) ve 138 (Burdur; AS) numaralı olanlar sirasiyla $25,00 \mathrm{~kg} / \mathrm{da}$ ve $26,00 \mathrm{~kg} / \mathrm{da}$ ile en düşük tane verim değerine sahip olmuşlar, bunları 28,00 kg/da verimle 130 (Isparta; AS), 131 (Isparta; AS) ve 136 (Burdur; AS) numaralı yerel çeşitler izlemiş̧ir. En yüksek tane verimi değerleri 62 (Muğla; AB), 35 (Antalya; $\mathrm{AB}$ ), 66 (Muğla; $A B$ ) ve 71 (Muğla; $A B$ ) numaralı yerel çeşitlerden (sırasıyla 145,00;151,00; 158,00 ve $168,00 \mathrm{~kg} / \mathrm{da}$ ) elde edilmiştir. Yerel çeşitlerin tane verimlerine göre dağılımları Şekil 2'de verilmiştir. Standart çeşitlerin tane verimleri $77,00 \mathrm{~kg} / \mathrm{da}$ ile $579,00 \mathrm{~kg} / \mathrm{da}$ arasında değișmiş, ortalamaları ise $312,00 \mathrm{~kg} / \mathrm{da}$ olmuştur. Sarı çeşidi standartlar içerisinde en yüksek tane verimine sahip olurken, bunu 423,00 kg/da ile Fetih izlemiştir. En düşük tane verimi ise Faikbey ve Seydişehir çeşitlerinden (sırasıyla $85,00 \mathrm{~kg} / \mathrm{da}$ ve $77,00 \mathrm{~kg} / \mathrm{da}$ ) elde edilmiştir. Standart çeşitlerin ortalamaları yerel çeşitlerin ortalamasından daha yüksek olmuştur. Tane verimi bakımından yerel çeşitler Faikbey ve Seydișehir çeşitleri hariç diğer standartlara göre oldukça düşük performans göstermişlerdir. $\mathrm{Bu}$ verim düşüklüğünün yerel çeşitlerin genetik yapılarından, yatmaya ve çoğunlukla hastalıklara karşı hassas olmalarından kaynaklandığı düşünülmektedir. Bazı araştırmacılar kara pas ve yulaf taçlı pası hastalıklarının asıl zararının yaprakta fotosentez alanının daralması ve iletim demetlerinin zarar görmesi sonucu oluştuğunu, hastalığın, epidemi yıllarında hassas çeşitler üzerinde \%90'a varan verim ve kalite kayıplarına neden olabildiğini belirtmişlerdir (Akan ve ark., 2012). Tamm (2003), hem genetik farklılı̆̆ın hem de iklim şartlarının yulafta tane verimini etkilediğini, aşırı rüzgâr ve yağmurun yulafta yatmaya neden olarak tane verimini düşürdügüüü saptamıştır. Naneli ve Sakin (2017), iki lokasyonda yürüttükleri araștırmada tane verimlerinin $211,30 \mathrm{~kg} / \mathrm{da}$ ile $501,50 \mathrm{~kg} / \mathrm{da}$ arasında değiştiğini, aradaki farkların \%1 seviyesinde önemli olduğunu bildirmişlerdir. Bu konuda yapılan bazı araştırmalarda da tane verimi yönünden, genotipler arasındaki farkların önemli olduğu tespit edilmiştir (Nawaz ve ark., 2004; Kara ve ark., 2007; Sar1 ve ark., 2016; Kahraman ve ark., 2017).

\section{Kavuzsuz tane oranı}

Araştırma sonucunda kavuzsuz tane oranı (KTO) bakımından yerel çeşitler arasındaki farklar önemsiz bulunmuştur. Yerel çeşitlere ait populasyonlar arası standart sapma 6,51 , değişim katsayısı $\% 10,49$ ve ortalamaları \%62,10 olarak belirlenmiştir (Çizelge 2). Yerel yulaf çeşitlerinin kavuzsuz tane oranları $\% 32,70$ ile \%78,20 arasında değişmiştir. Yerel çeşitlerden 129 (Isparta; AS) numaralı olan $\% 32,70$ ile en düşük kavuzsuz tane oranına sahip olmuş, bunu \%47,80 ile 104 (Antalya; AS) numaralı yerel çeşit izlemiştir. En yüksek kavuzsuz tane oranına 16 (Antalya; AB), 83 (Antalya; AS), 74 (Antalya; AS), 50 (Muğla; AB) ve 87 (Burdur; AS) numaralı yerel çeşitlerden (sırasıyla \%78,20; $\% 77,00 ; \% 74,10 ; \% 73,40$ ve $\% 73,10$ ) elde edilmiștir. Yerel çeşitlerin kavuzsuz tane oranlarına göre dağılımları Şekil 2'de verilmiştir. Burada yerel çeşitlerin \%55,00 ile \%70,00 arasında yoğunlaştığ1 tespit edilmiştir. Standart çeşitlerin kavuzsuz tane oranları \%48,70 ile \%71,10 arasında değişmiş, ortalamaları ise \%62,30 olmuştur. Kahraman çeşidi standartlar içerisinde en yüksek kavuzsuz tane oranına sahip olurken, bunu \%68,10 ile Yeniçeri izlemiștir. En düşük kavuzsuz tane oranı ise Faikbey ve Seydişehir çeşitlerinden (sırasıyla \%51,40 ve \%48,70) elde edilmiştir. Standart çeşitlerin ortalaması ile yerel çeşitlerin ortalaması yakın değerde olmuştur. Kahraman ve ark. (2017), genotiplerin tane iç oranlarının $\% 56,10$ ile $\% 78,40$ arasında değiştiğini bildirmiş̧lerdir. Yulaf bitkisi için kavuzsuz tane oranı önemli bir seleksiyon ölçütüdür. Erbaş (2012) ve Sarı (2012), kavuzsuz tane oranı bakımından çeşitler arasında önemli farklar bulunduğunu, Narlığlu (2015), kavuzsuz tane oranının çeşitlere göre önemli düzeyde 
farkl111k gösterdiğini ve $\% 58,00$ ile $\% 71,60$ arasında değiştiğini bildirmiştir. Yulaf üzerine yapılan bir araştırmada, tane/kavuz oranına, genotip ve çevrenin etkisinin hemen hemen eşit olduğunu ve yulaf taçlı pasının, yoğun görüldüğü yerlerde, kavuzsuz tane oranın düşük olmasına neden olduğu bildirilmiştir (Doehlert ve ark., 2001). Welch ve ark. (2000), kavuzsuz tane oranının \% 32,70 ile $\% 62,10$ arasında değiştiğini saptamıştır. Dokuyucu ve ark. (2010), yaptıkları araştırmada ilk yıl genotipler arasında kavuzsuz tane oranı bakımından önemli farkların tespit edildiğini, bu oranların $\% 75,37$ ile \%46,67 arasinda olduğunu, ancak ikinci yılda bu yönde bir seleksiyon yapıldığı için genotipler arasında önemli fark oluşmadığını belirtmiştir. Yulaf üzerine yapılan başka bir araştırmada, kavuzsuz tane oranı için, önemli genetik varyasyon ve yüksek kalıtım tespit edilmiştir (Buerstmayr ve ark., 2007).

\section{Bin tane ağırlı̆̆ı}

Bin tane ağırlığı (BTA) bakımından yerel çeşitler arasında önemli farklar bulunmuştur $(\mathrm{P}<0,01)$. Yerel çeşitlere ait populasyonlar arası standart sapma 6,23 g, değişim katsayısı \%23,60 ve ortalamaları 26,40 g olarak belirlenmiştir (Çizelge 2). Yerel yulaf çeşitlerinin bin tane ağırlıkları $12,10 \mathrm{~g}$ ile $46,80 \mathrm{~g}$ arasında değişmiştir. Yerel çeşitlerden 109 (Isparta; AS) numaralı olan en düşük bin tane ağırlı̆̆ına sahip olmuş, bunu 16,00 $\mathrm{g}$ ile 105 (Antalya; AS) numaralı yerel çeşit izlemiştir. En yüksek bin tane ağırlığı 46,80 g ile 66 (Muğla; AB) numaralı yerel çeşitten alınmış, bunu 65 (Muğla; AB), 67 (Muğla; AB), 64 (Muğla; $A B), 70$ (Muğla; $A B$ ) ve 58 (Muğla; $A B$ ) numaralı genotipler (bin tane ağırlıkları sirasıyla $44,00 \mathrm{~g}$, $42,10 \mathrm{~g}, 41,60 \mathrm{~g}$ ve 40,50 g) izlemiştir. Yerel çeşitlerin bin tane ağırlıklarına göre dağılımları Şekil 2'de verilmiştir. 17 adet yerel çeşidin bin tane ağırlığı 20,00 gramdan daha düşük olurken, $20,00 \mathrm{~g}$ ile 30,00 g arasında 108 adet yerel çeşit yer almıș, 30,00 gramdan yüksek bin tane ağırlığına sahip yerel çeşit sayısı ise 39 olmuştur. Standart çeşitlerin bin tane ağırlıkları 20,50 g ile 46,40 g arasında değişmiş, ortalamaları ise $34,10 \mathrm{~g}$ olmuştur. Kırklar çeşidi standartlar içerisinde en yüksek bin tane ağırlığına sahip olurken, bunu 45,10 g ile Sarı çeşidi izlemiştir. En düşük bin tane ağırlığı ise Faikbey ve Seydişehir çeşitlerinden (sırasıyla 26,40 g ve 20,50 g) elde edilmiştir. Standart çeşitlerin ortalaması yerel çeşitlerin ortalamasından yüksek bulunmuştur. Bin tane ağırlığı tahıllarda tane verimini etkileyen en önemli özelliklerden biridir. Mut ve ark.(2011), yaptıkları araştırmada genotiplerin bin tane ağırlıklarının birinci y1 19,87 $\mathrm{g}$ ile $39,82 \mathrm{~g}$, ikinci y1l ise $14,68 \mathrm{~g}$ ile $39,08 \mathrm{~g}$ arasında değiştiğini bildirmiştir. $\mathrm{Bu}$ sonuçlar ile bulgularımız benzerlik göstermektedir. Daha önce yulafta yapılan bazı çalışmalarda da bin tane ağırlığı yönünden çeşitler arasında önemli farklılıklar olduğu belirlenmiştir (Gül ve ark., 1999; Buerstmayr ve ark., 2007; Kara ve ark., 2007; Hışır, 2009; Maral, 2009; Dokuyucu ve ark., 2010; Erbaş, 2012; Sar1, 2012; Ceyhan, 2015; Narlıoğlu, 2015; Kahraman ve ark.,2017; Naneli ve Sakin, 2017). Bin tane ağırlığının çeşit özelliği olmasına rağmen (Dokuyucu ve ark.,2010), y1llara ve iklim koşullarına göre değişiklik gösterebileceği de bazı araştırmacılar tarafindan bildirilmiştir (Geçit ve Adak, 1988).

\section{Tane protein oranı}

Tane protein oranı (TPO) bakımından yerel çeşitler arasındaki farklar önemsiz bulunmuştur. Yerel çeşitlere ait populasyonlar arası standart sapma 2,21 , değişim katsayısı $\% 17,62$ ve ortalamaları $\% 12,52$ olarak belirlenmiştir (Çizelge 2). Yerel yulaf çeșitlerinin tane protein oranları \%7,56 ile \%21,25 arasında değişmiştir. Yerel çeşitlerden 126 (Isparta; AS) numaralı olan en düşük tane protein oranına sahip olmuş, bunu \%8,02 ile 98 (Burdur; AS) numaralı yerel çeşit izlemiştir. En yüksek tane protein oran $\% 21,25$ ile 134 (Burdur; AS) numaralı yerel çeşitten alınmış, bunu \%19,81, \%18,98 ve $\% 18,22$ oranlariyla sirasiyla 133 (Burdur; AS), 137 (Burdur; AS) ve 138 (Burdur; AS) numaralı yerel çeşitler takip etmiştir. Yerel çeşitlerin tane protein oranlarına göre dağılımları Şekil 2'de verilmiştir. Yerel çeşitlerin $\% 9,00$ ile $\% 16,00$ arasında yoğunlaştı̆̆ tespit edilmiştir. 6 adet yerel çeşidin tane protein oranları $\% 9,00$ 'dan daha düşük olurken, $\% 9,00$ ile $\% 16,00$ arasinda 150 adet yerel çeşit yer almış, \%16,00'dan yüksek tane protein oranlarına sahip 8 adet yerel çeşit bulunmuştur. Standart çeşitlerin tane protein oranları \%11,26 ile $\% 14,96$ arasında değişmiş, ortalamaları ise $\% 12,95$ olmuştur. Yeniçeri çeşidi standartlar içerisinde en yüksek tane protein oranına sahip olurken, bunu 
\%13,68 ile Sarı çeșidi izlemiștir. En düşük tane protein oranları ise Seydişehir ve Kırklar çeşitlerinden (sırasıyla \%11,26 ve \%11,31) elde edilmiştir. Sarı (2012), İzmir koşullarında iki yı1 yürüttüğü araştırmada protein oranı bakımından genotipler arasında önemli fakların olduğunu, birinci yıl yulaf hatlarının protein oranlarının $\% 8,44$ ile $\% 11,36$ arasında, standart çeşitlerde ise $\% 8,77$ ile $\% 10,37$ arasında değiştiğini bildirmiştir. Araştırmanın ikinci yılında hatların protein oranlarının \%10,50 ile \%17,83 arasında, standart çeşitlerin protein oranlarının ise $\% 9,47$ ile $\% 13,19$ arasında değiştiğini tespit etmiştir. $\mathrm{Bu}$ konuda yapılan bazı araştırmalarda tane protein oran1 bakımından genotipler arasındaki farklar önemli olurken (Erbaş, 2012; Naneli ve Sakin, 2017), bazı araştırmalarda ise genotipler arasındaki farklar önemsiz bulunmuştur (Hışır, 2009; Ceyhan, 2015; Narlıoğlu, 2015). Dokuyucu ve ark. (2010), iki y1l süreyle yürüttügü araştırmasında ilk yıl tane protein oranlarının \%10,26 ile \%15,96 arasında değiştiğini ve genotipler arasında önemli farkların olduğunu, ikinci yılda ise bu oranların \%11,44 ile $\% 14,81$ arasında değiştiğini ve genotipler arasında önemli bir fark çıkmadığını belirtmişlerdir. Mut ve ark. (2011), tane protein oranının ilk yıl \% 8,20 ile $\% 15,90$ arasında, ikinci y1l ise \%8,67 ile \%14,30 arasında değiștiğini bildirirken, Kahraman ve ark. (2015), araştırmalarında bu oranların \%12,60 ile $\% 16,50$ arasında değişim gösterdiğini, Kahraman ve ark. (2017) ise \%9,00 ile \%15,20 arasinda değiştiğini saptamışlardır. Welch ve ark. (2000), kavuzsuz tanenin protein oranlarının \%13,90 ile $\% 41,30$ arasında değiştiğini ve bir $A$. atlantica genotipinde, iki $A$. damascena genotipinde ve bir A. murphi genotipinde bu değerin \% 32,00'yi geçtiğini saptamışlardır.

\section{Tane yağ oranı}

Tane yă̆ oranı (YO) bakımından yerel çeşitler arasındaki farklar önemsiz bulunmuştur. Yerel çeşitlere ait populasyonlar arası standart sapma 0,81 , değişim katsayısı \%15,36 ve ortalamaları \%5,27 olarak belirlenmiştir (Çizelge 2). Yerel yulaf çeşitlerinin tane yağ oranları $\% 2,71$ ile
\%8,57 arasında değişmiştir. Yerel çeşitlerden 125 (Isparta; AS) numaralı olan en düşük tane yağ oranına sahip olmuş, bunu $\% 3,48$ ve $\% 3,52$ oranlar1 ile 120 (Isparta; AS) ve 154 (Burdur; AS) numaralı yerel çeşitler izlemiştir. En yüksek tane yağ oranı \%8,57 ile 60 (Muğla; $A B$ ) numaralı yerel çeşitten alınmış, bunu \%7,19, \%7,03, \%6,89 ve $\% 6,85$ oranlarıyla sirasiyla 64 (Muğla; AB), 12 (Antalya; AB), 101 (Burdur; AS) ve 62 (Muğla; AB) numaralı yerel çeşitler takip etmiştir. Yerel çeşitlerin tane yağ oranlarına göre dağılımları Şekil 2 'de verilmiştir. Yerel çeşitlerin büyük çoğunluğu (yaklaşık \%88'i) \%4,00 ile \%6,50 arasında tane yağ oranına sahip olmuştur. Yerel çeşitlerden 8 tanesi \%4,00'ten daha düşük, 11 tanesi \%6,50'den daha yüksek tane yağ oranına sahip olmuştur. Standart çeşitlerin tane yağ oranları $\% 4,21$ ile $\% 6,47$ arasında değişmiş, ortalamaları ise $\% 5,41$ olmuştur. Fetih çeşidi standartlar içerisinde en yüksek tane yă oranına sahip olurken, bunu \%6,08 ile Yeniçeri çeşidi izlemiştir. En düşük tane yağ oranları ise Kahraman ve Sarı çeşitlerinden sirasiyla $\% 4,21$ ve $\% 4,54$ oranlariyla elde edilmiştir. Hayvan beslenmesinde kullanılan yulaf tanesinin protein ve yağ oranının yüksek, beta glukan oranının düşük olması istenirken, insan beslenmesinde kullanılan yulaf tanesinin protein ve çözülebilir lif (beta glukan) oranının yüksek, yağ içeriğinin ise düşük olması istenir (Peterson ve ark., 2005). Sarı (2012), araştırmasında hatların yağ değerlerinin $\% 5,00$ ile $\% 8,00$ arasında, standart çeşitlerin yağ oranın ise $\% 5,35$ ile $\% 6,90$ arasında değiştiğini saptamıştır. Mut ve ark. (2011), yaptıkları araştırmada yulaf genotiplerinin yağ oranlarının ilk yıl \%2,63 ile \%7,94 arasında, ikinci yılda ise \%4,51 ile \%7,97 arasinda değiştiğini bildirmiştir. Erbaş (2012), çalışmasında genotipler arasında yağ oranları bakımından önemli farkların olduğunu ve bu oranların \%3,30 ile $\% 7,50$ arasında değiştiğini tespit etmiştir. $\mathrm{Bu}$ konuda yapılan diğer bir araştırmada genotipler arasında tane yağ oranı bakımından önemli farkların olduğu, genotiplerin yağ oranlarının $\% 4,60$ ile $\% 8,70$ arasında değiştiği bildirilmiştir (Sarı ve ark., 2016). 
Çizelge 2. Yerel yulaf çeşitlerinin incelenen özelliklerine dair değerleri.

Table 2. Values of oat landraces for the investigated traits.

\begin{tabular}{|c|c|c|c|c|c|c|c|c|c|c|c|c|}
\hline $\begin{array}{l}\text { ÇN } \\
\text { (LN) }\end{array}$ & $\begin{array}{c}\text { SGS } \\
\text { (DPE) }\end{array}$ & $\begin{array}{l}\text { FOS } \\
(\mathrm{DM})\end{array}$ & $\begin{array}{l}\text { SBS } \\
\text { (SNP) }\end{array}$ & $\begin{array}{c}\text { STS } \\
\text { (GNP) }\end{array}$ & $\begin{array}{c}\text { STA } \\
\text { (GWP) }\end{array}$ & $\begin{array}{c}\text { BV } \\
\text { (BY) }\end{array}$ & $\begin{array}{c}\text { TV } \\
(\mathrm{GY})\end{array}$ & $\begin{array}{l}\text { KTO } \\
\text { (GP) }\end{array}$ & $\begin{array}{c}\text { BTA } \\
\text { (TKW) }\end{array}$ & $\begin{array}{c}\text { TPO } \\
\text { (GPR) }\end{array}$ & $\begin{array}{c}\text { YO } \\
\text { (GOR) }\end{array}$ & $\begin{array}{c}\mathrm{Y} \\
\text { (L) }\end{array}$ \\
\hline 1 & 156,30 & 194,40 & 46,50 & 84,80 & 2,56 & 2718,00 & 75,00 & 64,60 & 30,20 & 12,96 & 5,51 & 7 \\
\hline 2 & 156,30 & 193,40 & 49,00 & 71,50 & 2,63 & 3101,00 & 105,00 & 59,30 & 36,80 & 12,25 & 5,40 & 7 \\
\hline 3 & 161,30 & 194,40 & 60,80 & 83,00 & 2,29 & 2818,00 & 65,00 & 57,00 & 27,80 & 11,36 & 4,69 & 9 \\
\hline 4 & 156,30 & 193,40 & 53,20 & 74,70 & 2,08 & 2101,00 & 102,00 & 59,30 & 28,10 & 12,77 & 4,43 & 9 \\
\hline 5 & 156,30 & 193,40 & 64,30 & 92,80 & 3,43 & 3518,00 & 91,00 & 63,00 & 36,70 & 10,48 & 5,03 & 7 \\
\hline 6 & 156,30 & 192,40 & 52,60 & 85,60 & 2,15 & 2101,00 & 102,00 & 51,60 & 25,30 & 14,30 & 3,81 & 9 \\
\hline 7 & 161,30 & 194,40 & 53,90 & 102,20 & 2,96 & 2768,00 & 72,00 & 62,60 & 28,90 & 10,61 & 4,58 & 9 \\
\hline 8 & 161,30 & 194,40 & 51,70 & 73,30 & 2,05 & 2534,00 & 75,00 & 53,10 & 28,30 & 11,69 & 5,29 & 9 \\
\hline 9 & 156,30 & 193,40 & 68,40 & 108,60 & 3,27 & 4268,00 & 91,00 & 59,20 & 29,80 & 10,78 & 5,68 & 7 \\
\hline 10 & 161,30 & 193,40 & 55,90 & 68,20 & 1,82 & 2184,00 & 74,00 & 56,00 & 27,20 & 13,00 & 4,91 & 9 \\
\hline 11 & 161,30 & 194,40 & 44,50 & 67,40 & 1,39 & 3284,00 & 83,00 & 66,50 & 21,50 & 12,74 & 5,50 & 9 \\
\hline 12 & 161,30 & 195,40 & 53,00 & 111,60 & 3,06 & 3751,00 & 77,00 & 64,70 & 27,20 & 11,04 & 7,03 & 9 \\
\hline 13 & 159,30 & 196,40 & 54,80 & 82,30 & 2,11 & 3268,00 & 81,00 & 56,40 & 25,90 & 14,24 & 5,60 & 9 \\
\hline 14 & 159,30 & 196,40 & 67,40 & 108,40 & 3,13 & 3468,00 & 79,00 & 57,20 & 28,70 & 12,93 & 6,56 & 9 \\
\hline 15 & 159,30 & 195,40 & 51,10 & 76,70 & 1,77 & 2801,00 & 78,00 & 58,60 & 23,50 & 13,32 & 5,72 & 7 \\
\hline 16 & 156,30 & 196,40 & 54,60 & 110,20 & 3,03 & 2168,00 & 96,00 & 78,20 & 27,30 & 14,07 & 5,31 & 9 \\
\hline 17 & 158,30 & 192,40 & 45,50 & 78,30 & 2,08 & 3351,00 & 115,00 & 61,60 & 26,90 & 14,60 & 5,34 & 9 \\
\hline 18 & 158,30 & 192,40 & 52,20 & 76,70 & 2,17 & 3334,00 & 125,00 & 60,60 & 28,60 & 13,98 & 5,30 & 7 \\
\hline 19 & 158,30 & 194,40 & 47,10 & 84,90 & 2,22 & 2884,00 & 90,00 & 62,40 & 26,30 & 12,53 & 4,16 & 7 \\
\hline 20 & 157,30 & 193,40 & 55,30 & 94,10 & 3,47 & 4101,00 & 118,00 & 63,00 & 36,60 & 13,12 & 5,78 & 7 \\
\hline 21 & 162,30 & 193,40 & 55,40 & 77,00 & 2,31 & 3751,00 & 97,00 & 49,30 & 30,20 & 13,29 & 4,89 & 7 \\
\hline 22 & 162,30 & 194,40 & 56,90 & 86,40 & 3,05 & 3118,00 & 108,00 & 62,70 & 35,20 & 12,67 & 5,87 & 7 \\
\hline 23 & 158,30 & 193,40 & 59,70 & 93,80 & 3,38 & 3984,00 & 127,00 & 63,80 & 35,80 & 12,77 & 5,71 & 7 \\
\hline 24 & 158,30 & 194,40 & 57,50 & 68,70 & 2,20 & 2868,00 & 108,00 & 61,00 & 32,30 & 14,15 & 6,19 & 9 \\
\hline 25 & 158,30 & 194,40 & 59,30 & 61,40 & 1,62 & 3168,00 & 110,00 & 62,40 & 27,10 & 15,25 & 5,40 & 7 \\
\hline 26 & 159,30 & 196,40 & 58,20 & 84,70 & 2,55 & 2634,00 & 86,00 & 60,60 & 30,20 & 13,77 & 5,11 & 7 \\
\hline 27 & 159,30 & 194,40 & 67,10 & 110,40 & 3,23 & 2684,00 & 94,00 & 50,80 & 29,10 & 12,15 & 6,00 & 7 \\
\hline 28 & 161,30 & 194,40 & 43,00 & 87,60 & 2,22 & 3501,00 & 110,00 & 63,60 & 25,50 & 12,94 & 5,52 & 9 \\
\hline 29 & 158,30 & 193,40 & 51,20 & 67,80 & 2,08 & 1984,00 & 79,00 & 62,70 & 31,10 & 15,73 & 5,56 & 9 \\
\hline 30 & 156,30 & 194,40 & 62,70 & 102,50 & 3,16 & 2051,00 & 110,00 & 64,20 & 30,70 & 14,77 & 5,43 & 9 \\
\hline 31 & 159,30 & 194,40 & 59,00 & 104,40 & 2,92 & 3201,00 & 85,00 & 62,40 & 27,80 & 14,63 & 4,76 & 9 \\
\hline 32 & 162,30 & 196,40 & 50,30 & 76,10 & 1,80 & 3218,00 & 63,00 & 59,60 & 24,10 & 15,66 & 5,06 & 9 \\
\hline 33 & 149,30 & 193,40 & 57,70 & 111,10 & 2,47 & 4418,00 & 88,00 & 56,00 & 22,20 & 14,32 & 5,25 & 9 \\
\hline 34 & 159,30 & 192,40 & 52,90 & 77,10 & 2,03 & 2568,00 & 69,00 & 59,20 & 26,70 & 16,56 & 4,99 & 9 \\
\hline 35 & 161,30 & 196,40 & 50,30 & 61,40 & 2,21 & 4184,00 & 151,00 & 49,60 & 36,30 & 15,94 & 4,34 & 9 \\
\hline 36 & 159,30 & 192,40 & 50,30 & 84,50 & 2,28 & 2151,00 & 97,00 & 62,00 & 27,10 & 13,80 & 6,29 & 9 \\
\hline 37 & 158,30 & 193,40 & 50,70 & 79,30 & 1,81 & 2634,00 & 97,00 & 53,80 & 23,30 & 14,08 & 5,30 & 9 \\
\hline 38 & 156,30 & 192,40 & 61,90 & 115,10 & 3,17 & 2534,00 & 121,00 & 62,90 & 27,30 & 12,77 & 5,85 & 9 \\
\hline 39 & 152,30 & 191,40 & 60,20 & 78,30 & 1,54 & 2218,00 & 87,00 & 62,80 & 20,20 & 13,12 & 5,07 & 9 \\
\hline 40 & 156,30 & 192,40 & 63,40 & 115,80 & 3,88 & 2034,00 & 77,00 & 66,30 & 33,10 & 12,60 & 5,87 & 9 \\
\hline 41 & 156,30 & 193,40 & 59,40 & 98,50 & 3,17 & 2451,00 & 113,00 & 65,30 & 32,00 & 13,29 & 5,7 & 9 \\
\hline 42 & 162, & & 62 , & & & 1796 & 91 & & 30 & 12,43 & 6,2 & 9 \\
\hline 43 & 157,10 & 193,10 & 43,30 & 85,60 & 2,22 & 2446,00 & 86,00 & 65,70 & 25,60 & 13,77 & 4,73 & 9 \\
\hline 44 & 159,10 & 193,10 & 53,80 & 95,80 & 2,30 & 2813,00 & 102,00 & 53,30 & 23,80 & 13,70 & 5,85 & 9 \\
\hline 45 & 160,10 & 193,10 & 46,30 & 95,90 & 2,78 & 3013,00 & 117,00 & 68,50 & 28,90 & 11,09 & 6,48 & 9 \\
\hline 46 & 157,10 & 192,10 & 44,90 & 69,20 & 1,60 & 2780,00 & 82,00 & 67,60 & 22,10 & 13,77 & 5,82 & 9 \\
\hline 47 & 159,10 & 193,10 & 50,50 & 100,80 & 2,96 & 1980,00 & 119,00 & 65,20 & 29,40 & 11,36 & 5,30 & 9 \\
\hline 48 & 160,10 & 193,10 & 35,50 & 52,70 & 1,59 & 2730,00 & 128,00 & 66,80 & 28,80 & 15,35 & 6,14 & 9 \\
\hline 49 & 163,10 & 193,10 & 40,30 & 66,90 & 2,10 & 3096,00 & 96,00 & 69,20 & 30,60 & 13,60 & 6,01 & 9 \\
\hline 50 & 159,10 & 192,10 & 42,20 & 84,60 & 2,95 & 3113,00 & 128,00 & 73,40 & 34,80 & 13,60 & 6,12 & 9 \\
\hline 51 & 159,10 & 193,10 & 64,20 & 110,30 & 3,33 & 1996,00 & 96,00 & 68,90 & 30,30 & 12,67 & 6,14 & 9 \\
\hline 52 & 153,10 & 192,10 & 41,40 & 95,60 & 2,33 & 1830,00 & 68,00 & 65,10 & 24,10 & 11,71 & 5,72 & 9 \\
\hline 53 & 157,10 & 193,10 & 55,20 & 100,00 & 2,70 & 2446,00 & 110,00 & 60,40 & 26,90 & 12,98 & 4,55 & 9 \\
\hline 54 & 157,10 & 193,10 & 38,50 & 57,10 & 2,16 & 1846,00 & 137,00 & 67,90 & 37,10 & 13,60 & 5,56 & 9 \\
\hline 55 & 157,10 & 194,10 & 48,00 & 91,20 & 2,45 & 1630,00 & 108,00 & 68,60 & 26,60 & 11,88 & 5,24 & 9 \\
\hline 56 & 157,10 & 193,10 & 60,40 & 92,80 & 3,30 & 2163,00 & 112,00 & 72,60 & 35,60 & 11,78 & 6,25 & 9 \\
\hline 57 & 150,10 & 192,10 & 41,80 & 78,80 & 2,82 & 1430,00 & 127,00 & 67,90 & 35,60 & 13,81 & 5,86 & 9 \\
\hline
\end{tabular}


Çizelge 2. Devam.

Table 2. Continued.

\begin{tabular}{|c|c|c|c|c|c|c|c|c|c|c|c|c|}
\hline $\begin{array}{l}\text { ÇN } \\
\text { (LN) }\end{array}$ & $\begin{array}{c}\text { SGS } \\
\text { (DPE) }\end{array}$ & $\begin{array}{l}\text { FOS } \\
\text { (DM) }\end{array}$ & $\begin{array}{c}\text { SBS } \\
\text { (SNP) }\end{array}$ & $\begin{array}{c}\text { STS } \\
\text { (GNP) }\end{array}$ & $\begin{array}{c}\text { STA } \\
\text { (GWP) }\end{array}$ & $\begin{array}{c}\text { BV } \\
\text { (BY) }\end{array}$ & $\begin{array}{c}\text { TV } \\
(\mathrm{GY})\end{array}$ & $\begin{array}{l}\text { KTO } \\
\text { (GP) }\end{array}$ & $\begin{array}{c}\text { BTA } \\
\text { (TKW) }\end{array}$ & $\begin{array}{c}\text { TPO } \\
\text { (GPR) }\end{array}$ & $\begin{array}{c}\mathrm{YO} \\
(\mathrm{GOR})\end{array}$ & $\begin{array}{c}\mathrm{Y} \\
\text { (L) }\end{array}$ \\
\hline 58 & 155,10 & 192,10 & 51,00 & 78,20 & 3,15 & 2863,00 & 109,00 & 63,20 & 40,30 & 12,74 & 5,27 & 9 \\
\hline 59 & 153,10 & 192,10 & 48,30 & 74,00 & 2,56 & 2246,00 & 138,00 & 71,00 & 34,30 & 12,95 & 6,51 & 9 \\
\hline 60 & 155,10 & 193,10 & 52,30 & 89,20 & 3,40 & 2113,00 & 135,00 & 66,90 & 38,30 & 11,02 & 8,57 & 9 \\
\hline 61 & 150,10 & 188,10 & 52,50 & 84,20 & 3,18 & 1096,00 & 117,00 & 67,60 & 37,80 & 12,19 & 6,31 & 9 \\
\hline 62 & 150,10 & 184,10 & 46,70 & 85,10 & 3,38 & 2313,00 & 145,00 & 72,40 & 39,90 & 11,85 & 6,85 & 9 \\
\hline 63 & 151,10 & 192,10 & 47,70 & 79,60 & 3,12 & 1613,00 & 130,00 & 57,70 & 39,20 & 12,98 & 6,33 & 9 \\
\hline 64 & 143,10 & 186,10 & 43,60 & 91,70 & 3,79 & 1896,00 & 138,00 & 72,00 & 41,60 & 12,33 & 7,19 & 9 \\
\hline 65 & 150,10 & 187,10 & 44,90 & 80,50 & 3,52 & 1563,00 & 130,00 & 63,40 & 44,00 & 13,57 & 6,58 & 9 \\
\hline 66 & 143,10 & 184,10 & 58,80 & 122,20 & 5,62 & 2430,00 & 158,00 & 71,40 & 46,80 & 13,26 & 6,50 & 9 \\
\hline 67 & 153,10 & 187,10 & 48,30 & 84,30 & 3,53 & 2080,00 & 133,00 & 70,20 & 42,10 & 12,19 & 5,25 & 9 \\
\hline 68 & 152,10 & 192,10 & 45,40 & 81,50 & 3,20 & 2063,00 & 138,00 & 66,80 & 39,40 & 12,88 & 6,25 & 9 \\
\hline 69 & 151,10 & 190,10 & 58,40 & 106,70 & 3,46 & 2580,00 & 114,00 & 62,00 & 32,60 & 11,98 & 5,82 & 9 \\
\hline 70 & 154,10 & 192,10 & 47,20 & 85,70 & 3,45 & 1496,00 & 117,00 & 68,60 & 40,50 & 9,54 & 6,59 & 9 \\
\hline 71 & 154,10 & 190,10 & 50,20 & 100,10 & 3,30 & 2480,00 & 168,00 & 67,50 & 33,10 & 10,85 & 6,43 & 7 \\
\hline 72 & 152,10 & 187,10 & 50,70 & 103,80 & 3,26 & 2013,00 & 113,00 & 70,90 & 31,50 & 10,68 & 4,81 & 9 \\
\hline 73 & 153,10 & 190,10 & 50,70 & 96,00 & 3,29 & 2280,00 & 127,00 & 58,60 & 34,30 & 10,20 & 6,43 & 9 \\
\hline 74 & 153,10 & 187,10 & 43,60 & 62,60 & 1,87 & 1313,00 & 69,00 & 74,10 & 28,80 & 9,13 & 5,42 & 9 \\
\hline 75 & 153,10 & 185,10 & 54,00 & 80,50 & 1,92 & 1313,00 & 65,00 & 68,10 & 23,20 & 10,95 & 5,46 & 9 \\
\hline 76 & 157,10 & 185,10 & 57,90 & 66,40 & 1,56 & 1813,00 & 60,00 & 61,40 & 22,30 & 11,98 & 5,55 & 9 \\
\hline 77 & 154,10 & 190,10 & 49,70 & 73,40 & 1,97 & 1505,00 & 57,00 & 62,20 & 26,10 & 11,09 & 5,85 & 9 \\
\hline 78 & 154,10 & 186,10 & 49,10 & 73,80 & 1,46 & 1280,00 & 60,00 & 62,60 & 18,80 & 14,12 & 4,76 & 9 \\
\hline 79 & 154,10 & 186,10 & 50,10 & 48,20 & 1,27 & 1296,00 & 63,00 & 56,70 & 24,20 & 9,78 & 5,20 & 9 \\
\hline 80 & 171,10 & 199,10 & 58,50 & 58,30 & 1,58 & 2413,00 & 136,00 & 55,20 & 25,70 & 9,61 & 5,69 & 3 \\
\hline 81 & 154,10 & 186,10 & 45,50 & 68,00 & 1,72 & 1696,00 & 59,00 & 57,20 & 24,30 & 12,40 & 5,78 & 9 \\
\hline 82 & 153,10 & 186,10 & 51,60 & 79,30 & 2,27 & 1896,00 & 72,00 & 72,50 & 28,10 & 11,36 & 4,64 & 9 \\
\hline 83 & 152,40 & 190,80 & 51,80 & 85,40 & 2,32 & 2125,00 & 88,00 & 77,00 & 28,00 & 10,43 & 5,24 & 5 \\
\hline 84 & 170,40 & 197,80 & 65,70 & 94,60 & 1,95 & 2192,00 & 109,00 & 52,00 & 21,80 & 9,29 & 4,26 & 3 \\
\hline 85 & 152,40 & 184,80 & 59,90 & 61,60 & 1,53 & 1309,00 & 76,00 & 68,70 & 26,10 & 9,36 & 5,74 & 7 \\
\hline 86 & 158,40 & 192,80 & 41,70 & 86,40 & 2,85 & 2742,00 & 109,00 & 66,70 & 33,40 & 8,98 & 6,80 & 9 \\
\hline 87 & 152,40 & 184,80 & 47,00 & 46,90 & 1,17 & 1059,00 & 61,00 & 73,10 & 26,50 & 10,36 & 5,15 & 9 \\
\hline 88 & 152,40 & 184,80 & 35,40 & 41,00 & 1,14 & 1642,00 & 69,00 & 63,60 & 29,10 & 9,33 & 5,09 & 9 \\
\hline 89 & 152,40 & 184,80 & 35,70 & 38,00 & 0,94 & 1542,00 & 68,00 & 57,40 & 26,50 & 12,84 & 6,10 & 9 \\
\hline 90 & 153,40 & 184,80 & 48,50 & 61,90 & 1,31 & 1625,00 & 67,00 & 68,60 & 22,60 & 13,87 & 5,17 & 9 \\
\hline 91 & 156,40 & 191,80 & 34,90 & 54,90 & 1,24 & 1475,00 & 71,00 & 65,60 & 24,10 & 8,64 & 5,40 & 9 \\
\hline 92 & 154,40 & 184,80 & 47,80 & 64,80 & 1,55 & 1909,00 & 67,00 & 57,70 & 25,10 & 9,40 & 5,51 & 9 \\
\hline 93 & 155,40 & 185,80 & 57,00 & 80,30 & 1,86 & 1292,00 & 65,00 & 65,20 & 24,30 & 10,43 & 5,33 & 9 \\
\hline 94 & 152,40 & 184,80 & 49,00 & 79,50 & 1,68 & 2659,00 & 74,00 & 69,40 & 22,30 & 11,05 & 5,27 & 9 \\
\hline 95 & 152,40 & 184,80 & 59,80 & 69,90 & 1,52 & 1525,00 & 75,00 & 69,40 & 23,10 & 9,05 & 4,81 & 9 \\
\hline 96 & 156,40 & 185,80 & 46,60 & 58,70 & 0,99 & 2059,00 & 62,00 & 53,10 & 18,80 & 10,26 & 3,65 & 9 \\
\hline 97 & 152,40 & 184,80 & 41,40 & 63,10 & 1,25 & 1959,00 & 72,00 & 61,00 & 21,40 & 9,40 & 5,31 & 9 \\
\hline 98 & 152,40 & 187,80 & 44,20 & 58,30 & 1,29 & 1759,00 & 69,00 & 68,30 & 23,70 & 8,02 & 5,45 & 9 \\
\hline 99 & 152,40 & 185,80 & 43,00 & 70,60 & 1,60 & 1659,00 & 79,00 & 68,50 & 23,90 & 8,64 & 5,61 & 9 \\
\hline 100 & 155,40 & 184,80 & 31,10 & 49,20 & 0,75 & 2309,00 & 61,00 & 61,40 & 17,80 & 10,29 & 5,40 & 9 \\
\hline 101 & 156,40 & 186,80 & 44,30 & 38,90 & 0,56 & 2342,00 & 61 & 63,40 & 17,40 & 9,91 & 6,89 & 9 \\
\hline 102 & 156,40 & 191,8 & 38,70 & 45 , & 0 & 2792,00 & 65 & 59,90 & 23,80 & 9,60 & 4,93 & 9 \\
\hline 103 & 152,40 & 185,80 & 64,70 & 56,50 & 0,84 & 1992,00 & 64,00 & 54,20 & 17,10 & 12,42 & 5,09 & 9 \\
\hline 104 & 170,40 & 197,80 & 66,50 & 87,10 & 1,85 & 2842,00 & 101,00 & 47,80 & 22,40 & 8,67 & 5,75 & 5 \\
\hline 105 & 156,40 & 184,80 & 34,60 & 37,50 & 0,47 & 1975,00 & 67,00 & 55,20 & 16,00 & 10,43 & 4,47 & 9 \\
\hline 106 & 156,40 & 183,80 & 45,20 & 54,70 & 1,01 & 2742,00 & 70,00 & 61,20 & 20,40 & 11,46 & 4,80 & 9 \\
\hline 107 & 155,40 & 184,80 & 36,20 & 65,40 & 1,26 & 1509,00 & 62,00 & 60,70 & 20,90 & 10,39 & 5,24 & 9 \\
\hline 108 & 156,40 & 185,80 & 39,60 & 60,70 & 0,97 & 1375,00 & 69,00 & 58,50 & 18,10 & 11,94 & 4,26 & 9 \\
\hline 109 & 154,40 & 187,80 & 33,00 & 49,50 & 0,44 & 1775,00 & 61,00 & 52,10 & 12,10 & 13,70 & 5,19 & 9 \\
\hline 110 & 164,40 & 192,80 & 38,90 & 33,00 & 1,05 & 2725,00 & 71,00 & 60,70 & 32,60 & 10,36 & 5,22 & 9 \\
\hline 111 & 153,40 & 188,80 & 31,40 & 66,30 & 1,14 & 1975,00 & 73,00 & 52,40 & 18,90 & 11,80 & 5,30 & 9 \\
\hline 112 & 154,40 & 187,80 & 36,40 & 58,20 & 1,19 & 1892,00 & 82,00 & 63,60 & 22,10 & 9,67 & 5,74 & 9 \\
\hline 113 & 155,40 & 185,80 & 39,70 & 50,00 & 1,14 & 1742,00 & 71,00 & 66,50 & 24,40 & 10,53 & 6,17 & 9 \\
\hline
\end{tabular}


Çizelge 2. Devam.

Table 2. Continued.

\begin{tabular}{|c|c|c|c|c|c|c|c|c|c|c|c|c|}
\hline $\begin{array}{l}\text { ÇN } \\
\text { (LN) }\end{array}$ & $\begin{array}{l}\text { SGS } \\
\text { (DPE) }\end{array}$ & $\begin{array}{l}\text { FOS } \\
\text { (DM) }\end{array}$ & $\begin{array}{c}\text { SBS } \\
\text { (SNP) }\end{array}$ & $\begin{array}{c}\text { STS } \\
\text { (GNP) }\end{array}$ & $\begin{array}{c}\text { STA } \\
\text { (GWP) }\end{array}$ & $\begin{array}{c}\text { BV } \\
\text { (BY) }\end{array}$ & $\begin{array}{c}\text { TV } \\
\text { (GY) }\end{array}$ & $\begin{array}{l}\text { KTO } \\
\text { (GP) }\end{array}$ & $\begin{array}{c}\text { BTA } \\
\text { (TKW) }\end{array}$ & $\begin{array}{c}\text { TPO } \\
\text { (GPR) }\end{array}$ & $\begin{array}{c}\mathrm{YO} \\
\text { (GOR) }\end{array}$ & $\begin{array}{c}\mathrm{Y} \\
(\mathrm{L})\end{array}$ \\
\hline 114 & 154,40 & 188,80 & 44,20 & 68,10 & 1,47 & 1825,00 & 74,00 & 69,10 & 23,00 & 11,94 & 5,45 & 9 \\
\hline 115 & 158,40 & 190,80 & 33,30 & 35,60 & 0,67 & 1725,00 & 61,00 & 50,30 & 21,50 & 14,14 & 5,44 & 9 \\
\hline 116 & 158,40 & 190,80 & 26,50 & 38,10 & 0,76 & 2542,00 & 55,00 & 59,20 & 22,40 & 12,56 & 4,77 & 9 \\
\hline 117 & 158,40 & 188,80 & 40,20 & 44,60 & 0,99 & 1959,00 & 62,00 & 67,20 & 24,10 & 11,46 & 4,65 & 9 \\
\hline 118 & 158,40 & 190,80 & 40,90 & 56,30 & 1,08 & 2559,00 & 59,00 & 55,80 & 21,00 & 11,46 & 4,48 & 9 \\
\hline 119 & 161,40 & 191,80 & 66,70 & 70,30 & 1,46 & 2575,00 & 58,00 & 49,10 & 22,20 & 13,11 & 4,55 & 9 \\
\hline 120 & 163,40 & 188,80 & 21,60 & 39,10 & 0,66 & 2075,00 & 58,00 & 56,40 & 19,70 & 11,46 & 3,48 & 9 \\
\hline 121 & 158,40 & 191,80 & 57,60 & 88,00 & 1,70 & 2242,00 & 64,00 & 67,60 & 20,60 & 9,60 & 5,29 & 9 \\
\hline 122 & 159,40 & 188,80 & 37,30 & 62,70 & 1,18 & 2975,00 & 57,00 & 53,20 & 20,50 & 9,95 & 4,79 & 9 \\
\hline 123 & 162,40 & 191,80 & 46,90 & 53,20 & 1,07 & 1909,00 & 61,00 & 55,70 & 21,90 & 12,42 & 4,37 & 9 \\
\hline 124 & 166,10 & 193,70 & 60,70 & 82,50 & 2,05 & 2577,00 & 32,00 & 50,60 & 23,90 & 13,55 & 4,18 & 7 \\
\hline 125 & 160,10 & 190,70 & 50,30 & 53,10 & 1,22 & 2244,00 & 25,00 & 50,30 & 21,50 & 15,71 & 2,71 & 9 \\
\hline 126 & 160,10 & 192,70 & 58,50 & 61,30 & 1,32 & 2544,00 & 48,00 & 63,20 & 20,00 & 7,56 & 4,86 & 9 \\
\hline 127 & 168,10 & 193,70 & 68,40 & 89,20 & 2,34 & 2544,00 & 29,00 & 55,20 & 25,40 & 13,41 & 4,40 & 9 \\
\hline 128 & 161,10 & 193,70 & 63,90 & 80,60 & 1,88 & 2761,00 & 40,00 & 55,20 & 22,30 & 14,72 & 4,84 & 9 \\
\hline 129 & 163,10 & 192,70 & 53,40 & 74,80 & 1,75 & 2394,00 & 32,00 & 32,70 & 22,40 & 15,68 & 3,92 & 7 \\
\hline 130 & 160,10 & 194,70 & 57,00 & 65,70 & 1,38 & 2561,00 & 28,00 & 49,90 & 19,60 & 14,23 & 5,22 & 9 \\
\hline 131 & 160,10 & 193,70 & 48,60 & 67,00 & 1,38 & 1827,00 & 28,00 & 52,60 & 19,10 & 15,54 & 4,42 & 9 \\
\hline 132 & 158,10 & 194,70 & 69,80 & 84,50 & 2,09 & 2627,00 & 36,00 & 61,00 & 23,70 & 16,09 & 4,41 & 9 \\
\hline 133 & 158,10 & 192,70 & 48,30 & 60,80 & 1,68 & 2411,00 & 36,00 & 60,30 & 26,90 & 19,81 & 4,68 & 9 \\
\hline 134 & 160,10 & 192,70 & 59,70 & 76,90 & 1,74 & 2611,00 & 33,00 & 60,20 & 21,40 & 21,25 & 4,53 & 9 \\
\hline 135 & 158,10 & 192,70 & 74,80 & 59,90 & 1,60 & 2344,00 & 41,00 & 63,50 & 25,80 & 15,27 & 4,45 & 9 \\
\hline 136 & 158,10 & 192,70 & 38,70 & 58,80 & 1,12 & 2277,00 & 28,00 & 64,80 & 17,30 & 16,50 & 4,44 & 9 \\
\hline 137 & 158,10 & 186,70 & 59,20 & 68,00 & 1,46 & 2011,00 & 32,00 & 57,30 & 20,10 & 18,98 & 4,57 & 9 \\
\hline 138 & 160,10 & 192,70 & 41,60 & 51,10 & 1,19 & 2294,00 & 26,00 & 59,60 & 21,90 & 18,22 & 4,20 & 9 \\
\hline 139 & 160,10 & 193,70 & 60,30 & 68,00 & 1,35 & 2277,00 & 33,00 & 66,30 & 18,30 & 14,34 & 4,46 & 9 \\
\hline 140 & 160,10 & 192,70 & 52,40 & 74,00 & 1,55 & 2894,00 & 33,00 & 65,00 & 19,70 & 13,06 & 3,58 & 9 \\
\hline 141 & 160,10 & 192,70 & 62,80 & 67,90 & 1,58 & 2427,00 & 31,00 & 65,60 & 22,10 & 11,52 & 4,97 & 9 \\
\hline 142 & 158,10 & 192,70 & 61,80 & 69,20 & 1,44 & 1927,00 & 34,00 & 60,70 & 19,30 & 11,96 & 3,60 & 9 \\
\hline 143 & 158,10 & 190,70 & 56,20 & 72,80 & 1,46 & 2411,00 & 32,00 & 61,90 & 18,70 & 12,38 & 4,85 & 9 \\
\hline 144 & 156,10 & 188,70 & 70,90 & 71,10 & 1,65 & 2161,00 & 36,00 & 63,20 & 22,10 & 13,75 & 4,95 & 9 \\
\hline 145 & 158,10 & 187,70 & 59,30 & 69,00 & 1,55 & 2294,00 & 31,00 & 59,20 & 21,20 & 11,76 & 5,00 & 9 \\
\hline 146 & 157,10 & 188,70 & 57,10 & 70,30 & 1,63 & 1594,00 & 46,00 & 61,50 & 22,00 & 13,13 & 5,04 & 9 \\
\hline 147 & 157,10 & 186,70 & 49,80 & 67,90 & 1,70 & 2427,00 & 43,00 & 63,10 & 24,00 & 11,96 & 5,75 & 9 \\
\hline 148 & 157,10 & 193,70 & 49,30 & 82,60 & 2,43 & 2411,00 & 56,00 & 64,10 & 28,90 & 9,97 & 5,95 & 7 \\
\hline 149 & 157,10 & 190,70 & 49,40 & 72,00 & 1,75 & 2761,00 & 31,00 & 65,60 & 23,30 & 15,20 & 5,45 & 7 \\
\hline 150 & 156,10 & 187,70 & 51,90 & 63,70 & 1,37 & 1794,00 & 41,00 & 59,00 & 20,20 & 12,89 & 4,62 & 9 \\
\hline 151 & 157,10 & 187,70 & 45,00 & 66,10 & 1,42 & 2494,00 & 41,00 & 62,20 & 20,10 & 10,86 & 5,45 & 7 \\
\hline 152 & 155,10 & 186,70 & 64,60 & 56,30 & 1,35 & 1911,00 & 47,00 & 63,70 & 22,70 & 11,17 & 4,70 & 7 \\
\hline 153 & 156,10 & 187,70 & 47,00 & 63,70 & 1,59 & 2111,00 & 39 & 65,00 & 23,90 & 12,65 & 4,80 & 7 \\
\hline 154 & 157,10 & 190,70 & 47,10 & 62,50 & 1,67 & 2577,00 & 37,00 & 64,00 & 25,80 & 11,24 & 3,52 & 9 \\
\hline 155 & 157,10 & 188,70 & 54,30 & 73,80 & 1,84 & 2027,00 & 49,00 & 67,70 & 23,90 & 10,79 & 4,75 & 7 \\
\hline 156 & 157,10 & 190,70 & 67,00 & 81,70 & 2,15 & 2761,00 & 39,00 & 59,30 & 25,50 & 12,55 & 4,67 & 9 \\
\hline 157 & 160,10 & 192,70 & 44,40 & 55,10 & 1,45 & 2711,00 & 30,00 & 58,10 & 25,40 & 16,19 & 4,94 & 9 \\
\hline 158 & 160,10 & 192,70 & 46,00 & 59,50 & 1,41 & 2211,00 & 32,00 & 63,80 & 22,40 & 14,89 & 4,82 & 9 \\
\hline 159 & 156,10 & 188,70 & 61,10 & 73,80 & 1,81 & 2311,00 & 36,00 & 65,90 & 23,50 & 12,72 & 5,82 & 9 \\
\hline 160 & 157,10 & 188,70 & 48,20 & 73,10 & 2,11 & 1894,00 & 38,00 & 63,00 & 28,20 & 13,82 & 4,62 & 9 \\
\hline 161 & 158,10 & 188,70 & 45,70 & 65,20 & 1,40 & 2344,00 & 32,00 & 61,80 & 20,10 & 13,72 & 4,51 & 9 \\
\hline 162 & 157,10 & 193,70 & 40,60 & 67,30 & 1,64 & 2294,00 & 46,00 & 61,00 & 23,40 & 12,93 & 4,59 & 9 \\
\hline 163 & 160,10 & 192,70 & 40,10 & 56,70 & 1,33 & 2727,00 & 32,00 & 67,80 & 22,10 & 15,47 & 4,35 & 9 \\
\hline 164 & 154,10 & 188,70 & 75,80 & 87,90 & 2,48 & 2694,00 & 92,00 & 71,30 & 27,50 & 12,00 & 5,07 & 5 \\
\hline St-1 & 165,50 & 193,00 & 44,50 & 44,90 & 1,20 & 2421,00 & 85,00 & 51,40 & 26,40 & 13,67 & 5,21 & 9 \\
\hline St-2 & 155,80 & 186,30 & 58,80 & 88,30 & 2,51 & 2846,00 & 423,00 & 66,10 & 28,50 & 12,51 & 6,47 & 1 \\
\hline St-3 & 151,80 & 185,80 & 59,40 & 97,10 & 3,79 & 3313,00 & 372,00 & 71,10 & 39,00 & 13,25 & 4,21 & 7 \\
\hline St-4 & 151,80 & 185,00 & 66,10 & 93,70 & 4,33 & 3700,00 & 312,00 & 63,20 & 46,40 & 11,31 & 5,66 & 7 \\
\hline St-5 & 135,50 & 182,30 & 57,50 & 99,00 & 4,45 & 3250,00 & 579,00 & 67,90 & 45,10 & 13,68 & 4,54 & 3 \\
\hline St-6 & 166,30 & 193,30 & 46,00 & 59,70 & 1,23 & 3204,00 & 77,00 & 48,70 & 20,50 & 11,26 & 5,67 & 9 \\
\hline St-7 & 157,50 & 191,30 & 66,90 & 113,70 & 3,74 & 4508,00 & 337,00 & 68,10 & 32,90 & 14,96 & 6,08 & 5 \\
\hline
\end{tabular}


Çizelge 2. Devam.

Table 2. Continued.

\begin{tabular}{|c|c|c|c|c|c|c|c|c|c|c|c|c|}
\hline $\begin{array}{l}\text { ÇN§ } \\
\text { (LN) }\end{array}$ & $\begin{array}{c}\text { SGS } \\
\text { (DPE) }\end{array}$ & $\begin{array}{l}\text { FOS } \\
\text { (DM) }\end{array}$ & $\begin{array}{c}\text { SBS } \\
\text { (SNP) }\end{array}$ & $\begin{array}{c}\text { STS } \\
\text { (GNP) }\end{array}$ & $\begin{array}{c}\text { STA } \\
\text { (GWP) }\end{array}$ & $\begin{array}{c}\text { BV } \\
\text { (BY) }\end{array}$ & $\begin{array}{c}\text { TV } \\
(\mathrm{GY})\end{array}$ & $\begin{array}{l}\text { KTO } \\
\text { (GP) }\end{array}$ & $\begin{array}{c}\text { BTA } \\
\text { (TKW) }\end{array}$ & $\begin{array}{c}\text { TPO } \\
\text { (GPR) }\end{array}$ & $\begin{array}{c}\mathrm{YO} \\
\text { (GOR) }\end{array}$ & $\begin{array}{c}\mathrm{Y} \\
\text { (L) }\end{array}$ \\
\hline St-Ort & 154,90 & 188,10 & 57,00 & 85,20 & 3,03 & 3320,00 & 312,00 & 62,30 & 34,10 & 12,95 & 5,41 & - \\
\hline Ort & 157,20 & 190,90 & 51,00 & 74,70 & 2,03 & 2354,00 & 77,40 & 62,10 & 26,40 & 12,52 & 5,27 & - \\
\hline Mak & 171,10 & 199,10 & 75,80 & 122,20 & 5,62 & 4418,00 & 168,00 & 78,20 & 46,80 & 21,25 & 8,57 & - \\
\hline Min & 143,10 & 183,80 & 21,60 & 33,00 & 0,44 & 1059,00 & 25,00 & 32,70 & 12,10 & 7,56 & 2,71 & - \\
\hline STDS & 4,10 & 3,54 & 9,74 & 18,43 & 0,85 & 640,27 & 33,30 & 6,51 & 6,23 & 2,21 & 0,81 & - \\
\hline CV 1 & 2,61 & 1,85 & 19,10 & 24,70 & 42,00 & 27,20 & 43,04 & 10,49 & 23,60 & 17,62 & 15,36 & - \\
\hline $\mathrm{F}$ & ** & ** & * & * & ** & ÖD & ** & ÖD & ** & ÖD & ÖD & - \\
\hline CV 2 & 0,70 & 0,40 & 11,50 & 15,10 & 21,60 & 29,70 & 19,50 & 11,10 & 9,10 & 14,20 & 10,90 & - \\
\hline LSD 1 & 1,67 & 1,19 & 8,82 & 17,08 & 0,70 & - & 32,41 & - & 3,73 & - & - & - \\
\hline LSD 2 & 2,83 & 2,02 & 14,91 & 28,86 & 1,18 & - & 54,78 & - & 6,30 & - & - & - \\
\hline
\end{tabular}

§ ÇN (LN): Yerel çeşit no (Landrace no); SGS (DPE): Salkım gösterme süresi (Days to panicle emergence); FOS (DM): Fizyolojik olum süresi (Days to maturity); SBS (SNP): Salkımda başakçık sayısı (Spikelet number per panicle); STS (GNP): Salkımda tane sayısı (Grain number per panicle); STA (GWP): Salkımda tane ağırlığı (Grain weight per panicle); BV (BY): Biyolojik verim (Biomass yield); TV (GY): Tane verimi (Grain yield); KTO (GP): Kavuzsuz tane oranı (Groat percentage); BTA (TKW): Bin tane ağırlığı (Thousand kernel weight); TPO (GPR): Tane protein oranı (Grain protein ratio); YO (GOR): Tane yağ oranı (Grain oil ratio); Y (L): Yatma (Lodging); St-1:Faikbey; St-2: Fetih; St-3:Kahraman; St-4: Kurklar; St-5: Sar1; St-6: Seydişehir; St-7: Yeniçeri; CV 1: Populasyonlar arası değişim katsayısı (\%) (Coefficient of variation among landraces); CV 2: Denemenin değişim katsayısı (\%) (Coefficient of variation of the experiment); St-Ort: Standart çeşitler ortalaması (Average of standart varieties); Ort: Yerel çeşitler ortalaması (Average of landraces); Mak: Maksimum (Maximum); Min: Minimum (Minimum); STDS: Yerel çeșitlerin standart sapması (Standard deviation of landraces); ÖD: Önemli değil (Non significant); $*: \mathrm{P}<0,05 ; * *: \mathrm{P}<0,01$

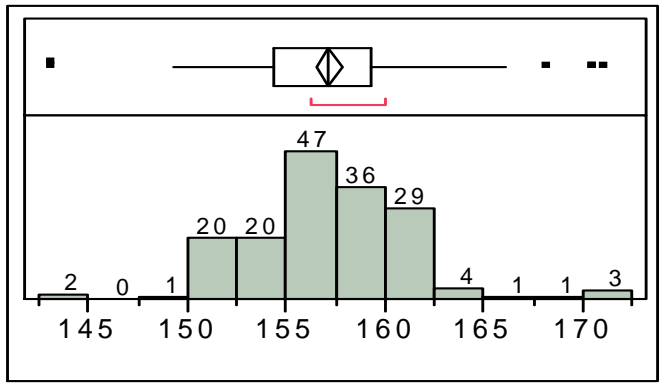

a) Salkım gösterme süresi (gün) (Days to panicle emergence).

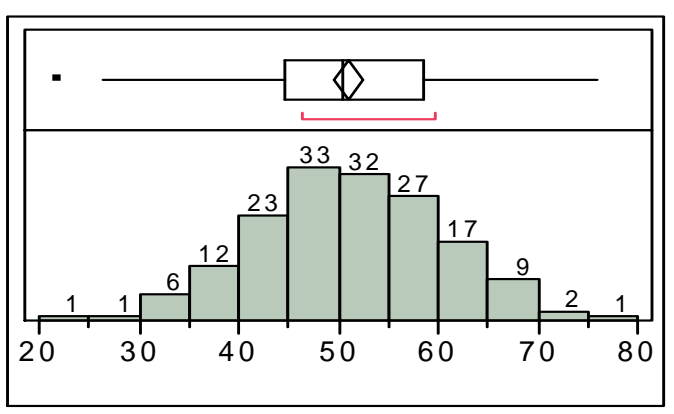

c) Salkımda başakçık sayısı (Spikelet number per panicle).

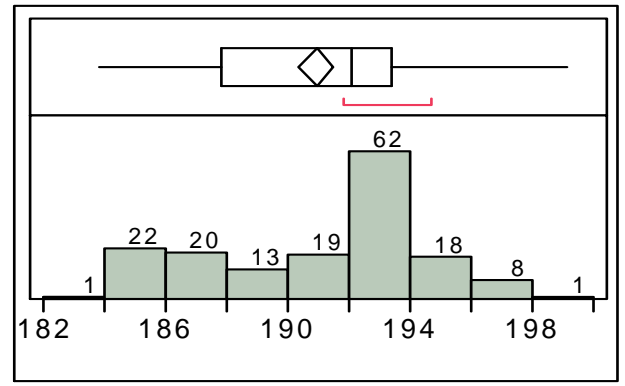

b) Fizyolojik olum süresi (gün) (Days to maturity).

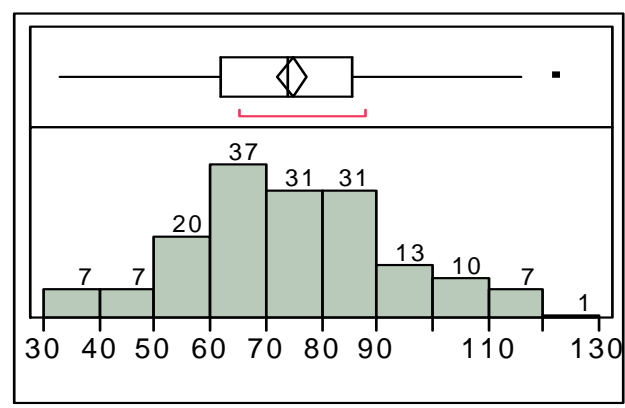

d) Salkımda tane sayısı (Grain number per panicle).

Şekil 2. Yerel yulaf çeşitlerinin incelenen özelliklere göre dağılımı.

Figure 2. Oat landraces distiribution for investigated traits. 


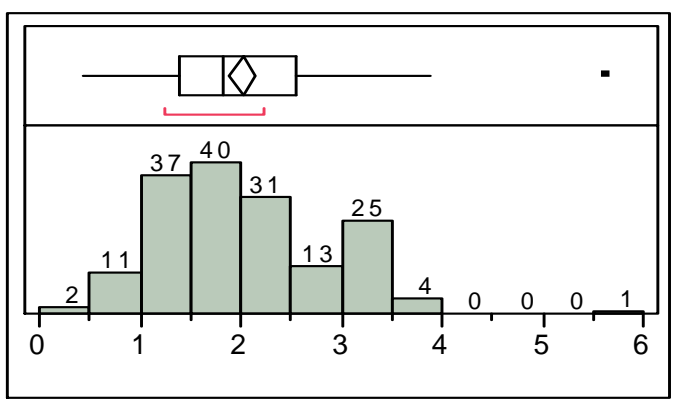

e) Salkımda tane ağırlığı (g) (Grain weight per panicle).

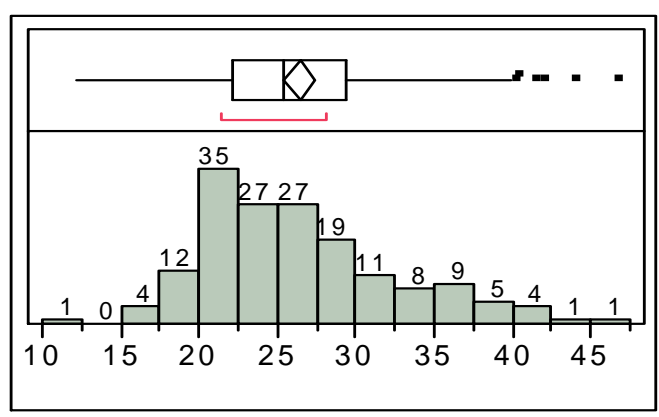

g) Bin tane ağırlığı (g) (Thousand kernel weight).

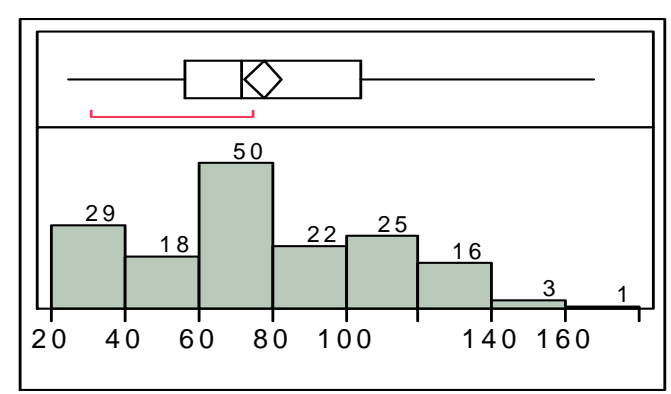

i) Tane verimi $(\mathrm{kg} / \mathrm{da})$ (Grain yield).

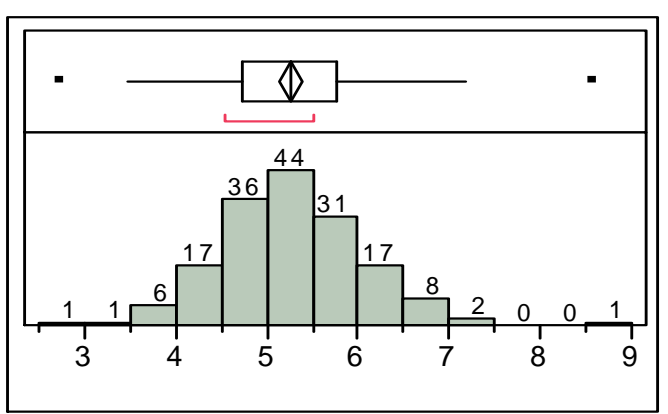

k) Tane yağ oranı (\%) (Grain oil ratio).

Şekil 2. Devam.

Figure 2. Continued.

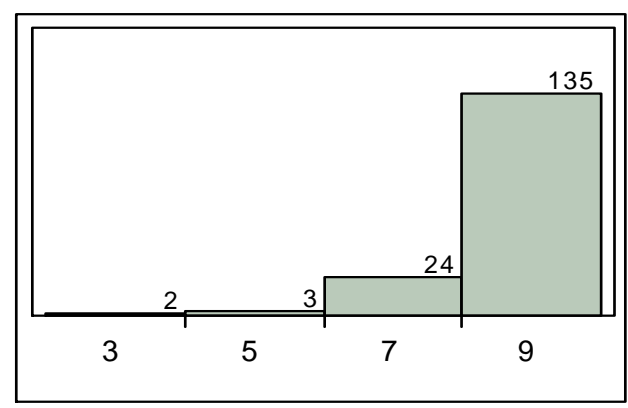

f) Yatma (Lodging).

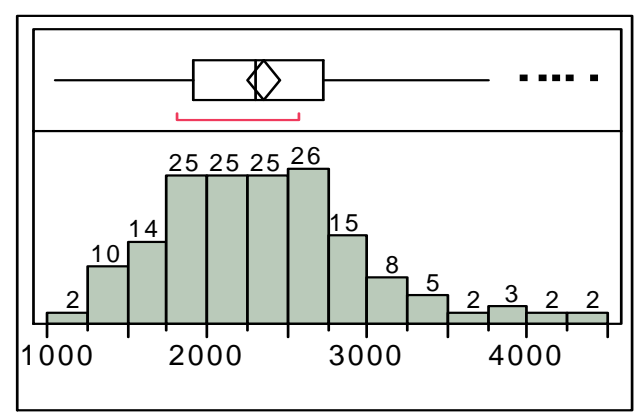

h) Biyolojik verim ( $\mathrm{kg} / \mathrm{da})$ (Biomass yield).

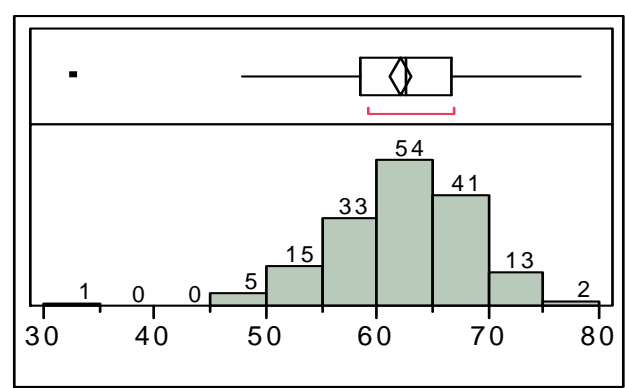

j) Kavuzsuz tane oranı (\%) (Groat percentage).

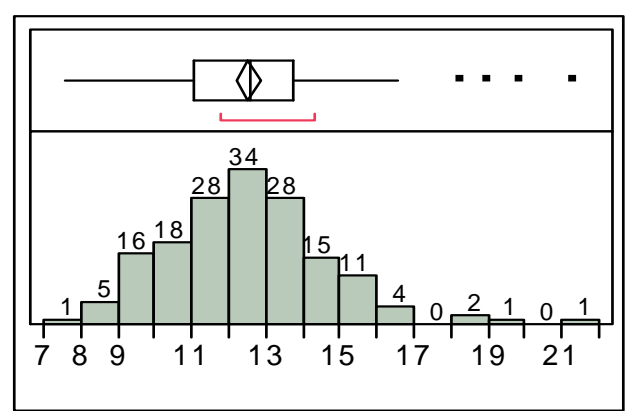

1) Tane protein oran $1(\%)$ (Grain protein ratio). 


\section{Tür ayrımı}

Değerlendirme sonucunda toplam 164 yerel çeşitten 74 adedinin Avena byzantina K. Koch, 90 adedinin Avena sativa $\mathrm{L}$. türüne ait olduğu belirlenmiştir (Şekil 3). Avena sativa L. türündeki yulafların 87 adedi 800 metreden daha yüksek rakımlı yerlerden toplanırken, 800 metrenin altında sadece 3 yerel çeşit toplanmıştır. Avena byzantina K. Koch türünde olanların çoğunluğu (70 adet) yüksekliği 800 metrenin altında olan yerlerden toplanmış, 800 metreden yüksek yerlerden ise 4 yerel çeşit toplanmıştır (Şekil 4). Elde ettiğimiz bu sonuçlara göre Batı Akdeniz Bölgesi'nin rakımı düşük olan sahil kuşağında yulaf tarımında $A$. byzantina $\mathrm{K}$. Koch türünün daha çok yetiştirildiği, rakımı 800 metreden yukarı olan iç kesimlerde ise A. sativa $\mathrm{L}$. türünün daha çok tercih edildiği görülmüştür.

\section{İncelenen özellikler arası ilişkiler}

İncelenen özellikler arasındaki ilişkilere ait korelasyon katsayıları Çizelge 3'te verilmiştir. TV ile BV, STS, STA, KTO, BTA ve YO arasinda önemli ve pozitif ilişki bulunurken, $Y$ ve SGS ile TV arasında önemli ve negatif ilişki saptanmıştır. SGS'nin uzamas1, tane dolum periyodunun daha sıcak döneme ötelenmesine ve tane dolum periyodunun kısalmasına yol açtı̆̆ından tane veriminde azalmaya sebep olduğu; bununla birlikte geç dönemde ortaya çıkan kara pas hastalığının da erkenci olan yerel çeşitlere göre geççi olanları daha fazla etkilediği ve bunun tane verimini düşürdüğü değerlendirilmektedir. BV ile SGS, FOS, STS, STA, BTA, TPO ve SBS arasında önemli ve pozitif ilişki

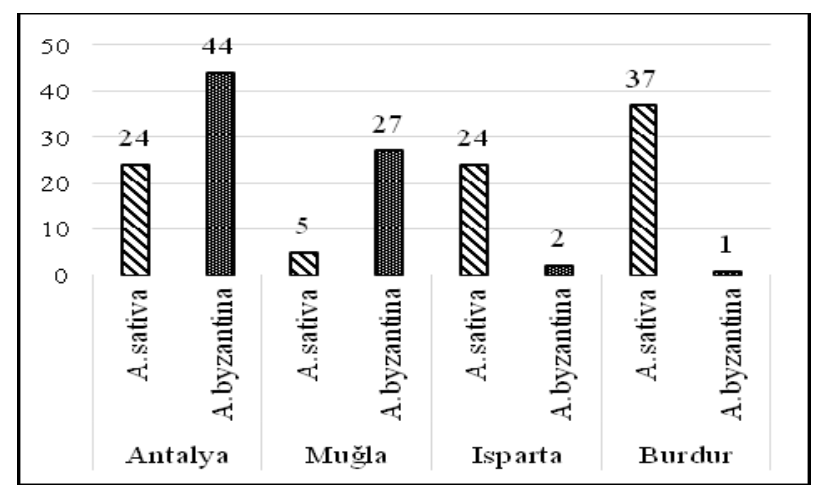

Şekil 3.Yerel çeşitlerin toplandığı illere ve botanik türüne göre dağ 1 lımı.

Figure 3. Distribution of oat landraces by provinces and botanical species. bulunurken, BV ile $\mathrm{Y}$ ve KTO arasında önemli ve negatif ilişki tespit edilmiştir. Yatmanın TV, BV, STS, STA, BTA ve SBS üzerinde önemli ve olumsuz etkisinin olduğu görülmüştür. SGS ile BV ve FOS arasında önemli pozitif ilişki bulunurken; STS, STA, KTO, BTA ve YO arasındaki ilişki önemli ve negatif yönlü olmuştur. FOS ile STS, STA ve SBS arasında pozitif önemli ilişki olduğu, FOS ile KTO arasındaki ilişkinin ise negatif ve önemli olduğu saptanmıştır. STS ile STA, KTO, BTA, YO ve SBS arasındaki ilişkilerin de önemli ve pozitif olduğu belirlenmiştir. STA ile KTO, BTA, YO ve SBS arasındaki ilişkiler önemli ve pozitif bulunmuştur. KTO ile BTA ve YO arasında pozitif yönlü önemli ilişkiler tespit edilmiş, KTO ile TPO arasında ise negatif yönlü önemli ilişkinin olduğu belirlenmiştir. BTA ile YO ve SBS arasında pozitif ve önemli ilişkiler tespit edilirken, TPO ile YO arasında negatif ve önemli ilişki bulunmuştur. Daha önce yulafla ilgili yapılan çalışmalarda da TV ile BV arasında ve BTA ile STA arasında pozitif ve önemli ilişki tespit edilmiştir (Güngör ve ark., 2017). Sarı ve Ünay (2015), yaptıkları çalışmada TV ile BTA, SBS, STS, STA ve YO arasinda önemli ve pozitif korelasyon; TV ile kavuz oranı arasında ise önemli ve negatif korelasyon belirlemişler, bu çalışmadaki bulgulara benzer bulgular elde etmişlerdir. Bu konuda yapılan başka bir araştırmada kavuzsuz tane oranının, tane verimi ile yüksek derecede ilişkili olduğu bildirilmiştir (Buerstmayr ve ark., 2007). Sürek ve Valentine (1996), tane veriminin, tane yağ oranı ile önemli ve pozitif ilişkiye sahip olduğunu saptamışlar, bizim bulgularımızla uyumlu sonuç elde etmişlerdir.

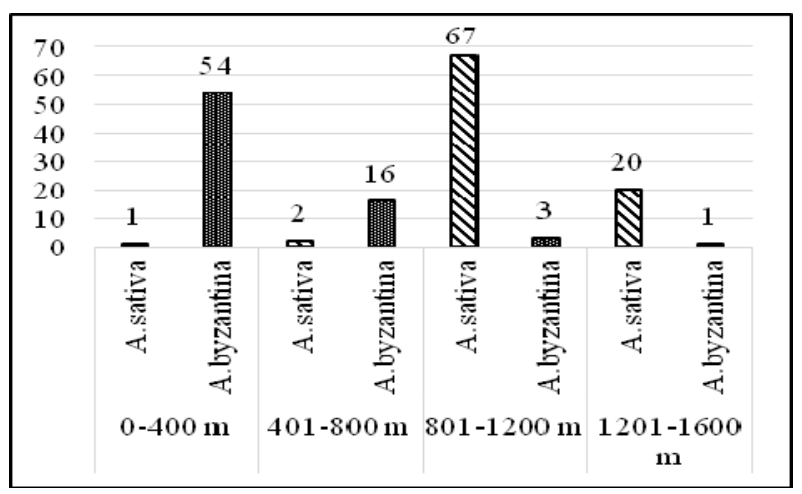

Şekil 4. Yerel çeşitlerin toplandığı rakıma ve botanik türüne göre dağılımı.

Figure 4. Distribution of oat landraces by altitude and botanical species. 
Çizelge 3. İncelenen özellikler arasındaki ilişkilere ait korelasyon katsayıları.

Table 3. The correlation coefficients of relation between investigated traits.

\begin{tabular}{|c|c|c|c|c|c|c|c|c|c|c|c|}
\hline $\begin{array}{l}\text { Özellikler } \\
\text { Traits }\end{array}$ & $\begin{array}{r}\text { BV } \\
\text { (BY) }\end{array}$ & $\begin{array}{r}\mathrm{Y} \\
(\mathrm{L})\end{array}$ & $\begin{array}{r}\text { SGS } \\
\text { (DPE) }\end{array}$ & $\begin{array}{r}\text { FOS } \\
(\mathrm{DM})\end{array}$ & $\begin{array}{r}\text { STS } \\
(\mathrm{GNP}) \\
\end{array}$ & $\begin{array}{r}\text { STA } \\
(\mathrm{GWP}) \\
\end{array}$ & $\begin{array}{l}\text { KTO } \\
\text { (GP) }\end{array}$ & $\begin{array}{r}\text { BTA } \\
(\mathrm{TKW}) \\
\end{array}$ & $\begin{array}{r}\text { TPO } \\
\text { (GRP) } \\
\end{array}$ & $\begin{array}{r}\mathrm{YO} \\
\text { (GOR) }\end{array}$ & $\begin{array}{r}\text { SBS } \\
(\mathrm{SNP})\end{array}$ \\
\hline \multirow{2}{*}{$\mathrm{TV}(\mathrm{GY})$} & $* *$ & $* *$ & $* *$ & ÖD & $* *$ & $* *$ & ** & $* *$ & ÖD & $* *$ & ÖD \\
\hline & 0,305 & $-0,539$ & $-0,385$ & $-0,130$ & 0,396 & 0,587 & 0,248 & 0,609 & $-0,037$ & 0,290 & 0,135 \\
\hline \multirow{2}{*}{ BV (BY) } & & $* *$ & $* *$ & $* *$ & $* *$ & ** & $*$ & ** & $* *$ & ÖD & $* *$ \\
\hline & & $-0,303$ & 0,281 & 0,463 & 0,348 & 0,315 & $-0,174$ & 0,202 & 0,240 & 0,019 & 0,272 \\
\hline \multirow{2}{*}{$\mathrm{Y}(\mathrm{L})$} & & & ÖD & ÖD & $* *$ & $* *$ & ÖD & $*$ & ÖD & ÖD & $* *$ \\
\hline & & & $-0,076$ & $-0,091$ & $-0,219$ & $-0,226$ & 0,024 & $-0,175$ & 0,106 & $-0,028$ & $-0,319$ \\
\hline \multirow{2}{*}{ SGS (DPE) } & & & & $* *$ & $*$ & ** & $* *$ & $* *$ & ÖD & $* *$ & ÖD \\
\hline & & & & 0,657 & $-0,152$ & $-0,327$ & $-0,479$ & $-0,370$ & 0,138 & $-0,255$ & 0,105 \\
\hline \multirow{2}{*}{ FOS (DM) } & & & & & $* *$ & * & ** & ÖD & $* *$ & ÖD & $* *$ \\
\hline & & & & & 0,292 & 0,168 & $-0,257$ & 0,058 & 0,303 & $-0,005$ & 0,245 \\
\hline \multirow{2}{*}{ STS (GNP) } & & & & & & ** & $* *$ & ** & ÖD & $* *$ & ** \\
\hline & & & & & & 0,856 & 0,242 & 0,489 & 0,047 & 0,320 & 0,568 \\
\hline \multirow{2}{*}{ STA(GWP) } & & & & & & & $* *$ & ** & ÖD & $* *$ & $* *$ \\
\hline & & & & & & & 0,360 & 0,855 & 0,042 & 0,453 & 0,423 \\
\hline \multirow{2}{*}{ KTO (GP) } & & & & & & & & ** & $*$ & $* *$ & ÖD \\
\hline & & & & & & & & 0,375 & $-0,190$ & 0,357 & $-0,022$ \\
\hline \multirow{2}{*}{ BTA(TKW) } & & & & & & & & & ÖD & $* *$ & * \\
\hline & & & & & & & & & $-0,010$ & 0,484 & 0,158 \\
\hline \multirow{2}{*}{ TPO (GRP) } & & & & & & & & & & ** & ÖD \\
\hline & & & & & & & & & & $-0,234$ & 0,130 \\
\hline YO (GOR) & & & & & & & & & & & $\begin{array}{r}\text { OD } \\
-0,015\end{array}$ \\
\hline
\end{tabular}

\section{SONUC}

Yerel çeşitler arasında salkımda tane sayısı ve tane ağırlığı, biyolojik verim, tane verimi ve bin tane ağırlığı bakımından yüksek varyasyonların olduğu belirlenmiştir. Yerel çeşitlerden elde edilen tane verimleri Faikbey ve Seydişehir çeşitleri hariç standart çeşitlerin verimlerinden daha düşük olmuștur. Bunun yatmaya ve hastalıklara karșı hassas olmalarından kaynaklandığ düşünülmektedir. Yerel çeşitlerden 66 (Muğla; AB) numaralı olan populasyon erkencilik, STS, STA ve BTA bakımından ümitvar bulunmuştur. Bununla birlikte 60 (Muğla; AB), 64 (Muğla; AB), 12 (Antalya; $\mathrm{AB}$ ), 101 (Burdur; AS) ve 62 (Muğla; $\mathrm{AB}$ ) numaralı yerel çeşitler de standart çeşitlerden daha yüksek tane yağ oranına sahip olmuşlardır. Tane protein oranına göre 134 (Burdur; AS), 133 (Burdur; AS), 137 (Burdur; AS) ve 138 (Burdur; AS) numaralı yerel çeşitler ön plana çıkmış ve standart çeşitlerden daha yüksek protein içeriğine sahip olmuşlardır. Bu yerel çeşitlerin kalite yönüyle sslah programlarında genitör olarak kullanılabileceği değerlendirilmektedir. Tanımlamaları yapılan yerel yulaflardan tohum örnekleri Türkiye Tohum Gen Bankasina gönderilmiştir. Genetik kaynaklarımızın korunması, gelecekte bitki 1slahçılarının genetik kaynak ihtiyacının karşılanması ve ülke tarımının geleceği açısından bu ve benzeri araştırmaların ülkemizin çalışılmayan bölgelerinde de yürütülmesi yararlı olacaktır.

\section{TEŞEKKÜR}

$\mathrm{Bu}$ araştırma faaliyeti Türkiye Bilimsel ve Teknolojik Araştırma Kurumu (TÜBITAK) tarafindan TOVAG 2140679 numaralı proje ile desteklenmiştir. 


\section{LITERATÜR LISTESI}

Akan, K., Z. Mert, L. Çetin, A. Salantur, S. Yazar, E. Dönmez, B. Özdemir, S. Yalçın, Y. Özer ve R. Wanyera. 2012. Bazı buğday genotiplerinin lokal sarı pas ve kara pas irklarıla ug99 kara pas irkına reaksiyonlarının belirlenmesi. Tarla Bitkileri Merkez Araştırma Enstitüsü Dergisi 21 (1): 22-31.

Akay, H., Z. Mut, M. C. Bahadır ve Ö. D. Erbaş Köse. 2019. Yulafın insan beslenmesi ve sağlık açısından önemi. 5th Int. Eurasian Congress on 'Natural Nutrition, Healthy Life \& Sport. 02-06 October 2019. Ankara. s. 464-471.

Anonim. 2007. Ulusal Biyolojik Çeşitlilik Stratejisi ve Eylem Planı. T.C. Çevre ve Orman Bakanlığı, Doğa Koruma ve Milli Parklar Genel Müdürlüğü. Baskı: Tasarım Ofset, 1. Bask1. Ankara.

Anonim. 2016. Meteoroloji Genel Müdürlüğü, resmi istatistikler. https://www.mgm.gov.tr/veridegerlendir me/il-ve-ilceler-istatistik. aspx?m=ANTALYA.

Anonymous. 1990. Association of Official Analytical Chemists (AOAC): in: Official Methods of Analysis of the Association of Official Analytical Chemists, 15th ed., Protein Determination: Method 979.09. Arlington, VA, USA.

Anonymous. 2005. Official Method of Analysis, Method 945.16. Oil in Cereal Adjuncts. 18th ed. AOAC International, Gaithersburg, MD.

Anonymous. 2007. JMP® 7.0, Copyright (C) 2007, SAS Institute Inc., Cary, NC, USA.

Anonymous. 2020. Food and Agriculture Organization of the United Nations, Statistical Databases. Available at: http://www.fao.org/faostat/en/\#data/QC.

Batalova, G. A., S. N. Shevchenko, M. V. Tulyakova, I. I. Rusakova, V. A. Zheleznikova., and E.M. Lisitsyn. 2016. Breeding of naked oats having high-quality grain. Russian Agricultural Sciences 42 (6): 407-410. Doi: $10.3103 / \mathrm{S} 1068367416060045$.

Buerstmayr, H., N. Krenn, U. Stephan, H. Grausgruber., and E. Zechner. 2007. Agronomic performance and quality of oat (Avena sativa L.) genotypes of worldwide origin produced under Central European growing conditions. Field Crops Res. 101: 343-351. Doi: 10.1016/j.fcr. 2006.12 .011

Ceyhan, M. 2015. Bazı yulaf çeşitlerinin Adana ve Kahramanmaraş lokasyonlarında verim ve verim unsurları bakımından değerlendirilmesi. Yüksek lisans tezi. K.S.Ü. Fen Bil. Ens. Tarla Bitkileri Ana Bilim Dalı, Kahramanmaraş.

Davis, P. H., R. R Mill, and K. Tan. 1985. Flora of Turkey and the East Aegean Islands. Vol. 9, Edinburgh University Press. Edinburgh, Scotland.

Doehlert, D. C., M. S. Mcmullen., and J. J. Hammond. 2001. Genotypic and environmental effects on grain yield and quality of oat grown in North Dakota. Crop Sci. 41: 1066-1072. Doi: 10.2135/cropsci2001.4141066x.
Dokuyucu, T., A. Akkaya, Z. Dumlupınar ve R. Kara. 2010. Türkiye orijinli yulaf genotiplerinde morfolojik ve agronomik özellikler yönünden varyasyonların belirlenmesi. TÜBİTAK TOVAG 1060583 no'lu proje sonuç raporu.

Dreccer, M. F., A. F. Herwaarden., and S. C. Chapman. 2009. Grain number and grain weight in wheat lines contrasting for stem water soluble carbohydrate concentration. Field Crops Res. 112 (1): 43-54. Doi: 10.1016/j.fcr.2009.02.006.

Dumlupınar, Z. 2010. Türkiye orijinli yerel yulaf genotiplerinin avenin proteinleri ile morfolojik, fenolojik ve agronomik özellikler yönünden karakterizasyonu. Doktora tezi. K.S.Ü. Fen Bil. Ens. Tarla Bitkileri Ana Bilim Dalı, Kahramanmaraş.

Dumlupınar, Z., T. Dokuyucu ve Y. Bölek. 2015. Farklı gen bankalarından elde edilen yulaf hatlarının, tarımsal ve moleküler karakterizasyonu. TÜBİTAK TOVAG $112 \mathrm{O} 138$ no'lu proje sonuç raporu.

Dumlupınar, Z., A. Tekin, S. Herek, A. Tanrıkulu, T. Dokuyucu ve A. Akkaya. 2017. Türkiye kökenli yulaf genotiplerinin bazı tarımsal özellikler bakımından değerlendirilmesi. Türk Tarım - Gıda Bilim ve Teknoloji Dergisi 5 (7): 763772. Doi: 10.24925/turjaf.v5i7.763-772.1181

Erbaş, Ö. D. 2012. Yulaf (Avena sativa L.) genotiplerinin tarımsal ve bazı kalite özelliklerinin belirlenmesi. Yüksek lisans tezi. Bozok Ün. Fen Bil. Ens. Tarla Bitkileri Ana Bilim Dalı, Yozgat.

Ercan K., A. Tekin, S. Herek, A. Kurt, E. Kekeç, M.F. Olgun, T. Dokuyucu ve A. Akkaya. 2016. Yerel yulaf hatlarının Kahramanmaraş koşullarındaki performansı. K.S.Ü Doğa Bilimleri Dergisi 19 (4): 438-444.

Ergün, N. ve H. H. Geçit. 2008. İleri kademe arpa (Hordeum vulgare L.) hatlarında verim ve verime etkili bazı karakterlerin incelenmesi. Ülkesel Tahıl Sempozyumu. 2-5 Haziran 2008. Konya. s. 14-23.

Geçit, H. H. ve M. S. Adak. 1988. Osman Tosun Gen Bankasındaki 1-96 sıra numaralı arpa materyalinde bazı morfolojik ve fizyolojik özelliklerin belirlenmesi. Ankara Üniversitesi Ziraat Fakültesi Dergisi 39: 326-335.

Geçit, H. H. ve N. Şahin, 1999. Yulafta ekim sıklıklarına göre anasap ve çeşitli kademedeki kardeşlerde bazı verim öğelerinin değișimi. Türkiye 3. Tarla Bitkileri Kongresi. 15-18 Kasım 1999. Adana. s. 192-197.

Gül, İ., C. Akıncı, ve M. Çölkesen. 1999. Diyarbakır koşullarına uygun tane ve ot amaçlı yetiştirilebilecek yulaf çeşitlerinin belirlenmesi. Orta Anadolu'da Hububat Tarımının Sorunları ve Çözüm Yolları Sempozyumu. 8-11 Haziran 1999. Konya. s. 117-125.

Güner, A., S. Aslan, T. Ekim, M. Vural ve M. T. Babaç. 2012. Türkiye Bitkileri Listesi (Damarlı Bitkiler). Nezahat Gökyiğit Botanik Bahçesi ve Flora Araștırmaları Derneği yayını. İstanbul. ISBN: 978-605-60425-7-7.

Güngör, H., T. Dokuyucu, Z. Dumlupınar ve A. Akkaya. 2017. Yulafta (Avena spp.) tane verimi ile bazı tarımsal özellikler arasındaki ilişkilerin korelasyon ve path analizleriyle saptanmas1. Tekirdağ Ziraat Fakültesi Dergisi 14 (01): 61-68. 
Hışır, Y. 2009. Türkiye yulaf genotiplerinin fizyolojik, morfolojik ve tarımsal özellikler yönünden genetik farklılıklarının ve ilerlemelerinin belirlenmesi. Doktora tezi. K.S.Ü. Fen Bil. Ens. Tarla Bitkileri Ana Bilim Dalı, Kahramanmaraş.

Kahraman, T., R. Avc1 ve C. Kurt. 2015. Trakya- Marmara Bölgesinde bazı yulaf (Avena sativa L.) genotiplerinin tane verimi, kalite ve tarımsal özelliklerinin araştırılması. 11. Tarla Bitkileri Kongresi. 7-10 Eylül 2015. Çanakkale. s. 204-207.

Kahraman, T., R. Avc1 ve C. Kurt. 2017. Bazı yulaf (Avena sativa L.) genotiplerinin tane verimi, kalite ve tarımsal özelliklerinin belirlenmesi. Tarla Bitkileri Merkez Araştırma Enstitüsü Dergisi 26 (Özel Sayı): 74-79. Doi: $10.21566 /$ tarbitderg.359164.

Kara, R., Z. Dumlupınar, Y. Hışır, T. Dokuyucu ve A. Akkaya. 2007. Kahramanmaraş koşullarında yulaf çeşitlerinin tane verimi ve verim unsurları bakımından değerlendirilmesi. Türkiye VII. Tarla Bitkileri Kongresi. 25-27 Haziran 2007. Erzurum. s. 121-125.

Kün, E. 1988. Serin İklim Tahılları. Ankara Üniv. Zir. Fak. Yay. No: 1032, Ders Kitab1 No: 299. Ankara.

Malzew, A.I. 1930. Wild and cultivated oats (Sectio Euavena Griseb). Bul. Appl. Bot., Gen. and Plant Breeding. Suppl. 38. s. 473-517, Leningrad.

Maral, H. 2009. Yulaf çeşitlerinin azotlu gübrelemeye tane verimi, azot kullanımı ve verim özellikleri yönünden tepkisi. Yüksek lisans tezi. K.S.Ü. Fen Bil. Ens. Tarla Bitkileri Ana Bilim Dalı, Kahramanmaraş.

Mut, Z., A. Gülümser ve İ. Sezer. 2011. Karadeniz Bölgesi yerel yulaf çeşitlerinin toplanması, tanımlanması, bazı tarımsal ve kalite özelliklerinin belirlenmesi. TÜBİTAK TOVAG 1070802 no'lu proje sonuç raporu.

Naneli, İ. ve M.A. Sakin. 2017. Bazı yulaf çeşitlerinin (Avena sativa L.) farklı lokasyonlarda verim ve kalite parametrelerinin belirlenmesi. Tarla Bitkileri Merkez Araştırma Enstitüsü Dergisi 26 (Özel Sayı): 37-44. Doi: $10.21566 /$ tarbitderg.359057.

Narlıoglu, A. 2015. Bazı yulaf genotiplerinin verim ve kalite kriterleri ile silaj özellikleri bakımından değerlendirilmesi. Yüksek lisans tezi. K.S.Ü. Fen Bil. Ens. Tarla Bitkileri Ana Bilim Dalı, Kahramanmaraş.

Nawaz, N., A. Razzaq, Z. Ali, G. Sarwar., and M. Yousaf. 2004. Performance of different oat (Avena sativa $\mathrm{L}$.) varieties under the agro-climatic conditions of BahawalpurPakistan. Int. J. Agri. Biol. 6 (4): 624-626.

Petersen, R.G. 1994. Agricultural Field Experiments: Design and Analysis. Marcel Dekker, Inc. ISBN 0824789121. NY, USA.

Peterson, D. M., D. M. Wesenberg, D. E. Burrup., and C. A. Erickson. 2005. Relationships among agronomic traits and grain composition in oat genotypes grown in different environments. Crop Sci. 45:1249-1255. Doi:10.2135/cropsci2004.0063.
Rechinger, K. H. 1970. Flora Iranica: Gramineae. Vol. 70: 322-331. Akademische, Druck und Verkagsanstalt Graz, Austria.

Sabandüzen, B. ve M. Akçura. 2017. Bazı yulaf genotiplerinin Çanakkale koşullarında verim ve verim unsurlarının incelenmesi. Türk Tarım ve Doğa Bilimleri Dergisi 4 (2): 101-108.

Sainio, P. P., and P. Jarvinen. 1995. Seeding rate effects on tillering, grain yield, and yield components of oat at high latitude. Field Crops Res. 40: 49-56.

Sar1, N. 2012. Yulafta (Avena sativa L.) verim ve verim komponentleri arasındaki ilişkiler. Yüksek lisans tezi. Adnan Menderes Ün. Fen Bil. Ens. Tarla Bitkileri Ana Bilim Dalı, Aydın.

Sarı, N. ve A. Ünay. 2015. Yulafta (Avena sativa L.) tane verimini etkileyen özelliklerin belirlenmesi. Tarla Bitkileri Merkez Araştırma Enstitüsü Dergisi 24 (2): 115-123. Doi:: 10.21566/tbmaed.76925.

Sarı, N., A. İmamoğlu, S. Pelit, Ö. Yıldız ve C. Büyükkileci. 2016. Ege Bölgesi sahil kuşağına uygun yulaf (Avena sativa L.) genotiplerinin belirlenmesi. Tarla Bitkileri Merkez Araştırma Enstitüsü Dergisi 25 (Özel sayı-1): 158-164. Doi: 10.21566/tarbitderg.280332.

Sürek, H. ve J. Valentıne. 1996. Kültürü yapılan yulafta (Avena sativa L.) bazı kantitatif karakterler arasındaki ilişkiler ve kalıtım dereceleri. Ankara Üniversitesi Ziraat Fakültesi Tarım Bilimleri Dergisi 2 (3): 39-43.

Şener, A., N. Çelik, F. Demir, M. Kaya. 2017. Makarnalık buğday (Triticum durum Desf.)'da Trinexapac-Ethyl uygulamasının tane verimi ve kalite özellikleri ile yatmaya karş1 etkileri. Türkiye 12.Tarla Bitkileri Kongresi. 12-15 Eylül 2017. Kahramanmaraş. s. 23-27.

Tamm, I. 2003. Genetic and environmental variation of grain yield of oat varietes. Agronomy Research 1: 93-97.

Tiwari U., and E. Cummins. 2009. Simulation of the factors affecting ßeta-glucan levels during the cultivation of oats. Journal of Cereal Science 50 (2): 175-183. Doi: 10.1016/j.jcs.2009.04.014.

Tsikitis V. L., J. E. Albina., and J. S. Reichner. 2004. ßetaglucan affects leukocyte navigation in a complex chemotactic gradient. Surgery 2: 384-9. Doi: 10.1016/j.surg.2004.05.014.

Tutin, E. D., V. H. Heywood, N. A. Burges, D. H. Valentine, S. M. Walters, and D. A. Webb. 1980. Flora Europaea: Alismataceae to Orchidaceae (Monocotyledones). Vol. 5, 452 pp. Cambridge University Press, Cambridge, UK.

Welch, R. W., J. C. W. Brown., and M. Leggett. 2000. Interspesific and intraspesific variation in grain and groat charesteristics of wild oat (Avenea) species: Very high groat $(1,3),(1,4)-\beta$-D-Glucan in an Avena atlantica genotype. Journal of Cereal Science 31 (3): 273-279. Doi: 10.1006/jcrs.2000.0301.

Yurtsever, N. 1984. Deneysel İstatistik Metotları. Toprak ve Gübre Araştırma Enst. Müd. Yayınları Genel Yayın No: 121. Ankara. 